\title{
Reflexiones sobre el significado del ateísmo y la idolatría para la teología
}

\author{
JON SOBRINO \\ Centro de Reflexión Teológica, San Salvador.
}

Es ya un tópico afirmar que ateismo e idolatría son realidades en nuestro mundo de hoy que de forma distinta niegan la realidad de Dios y hacen ambientalmente difícil la fe en Dios. Asi en un reciente congreso de teologia sobre Dios se ha mencionado el reto de la secularización ateísmo y el reto de los idolos de muerte. ${ }^{1}$ Con lo primero se quiere afirmar la existencia del ateísmo ambiental como realidad socio-cultural extendida en el primer mundo; con lo segundo se quiere afirmar una realidad histórica, socio-económico-política que en si misma contradice la realidad y la voluntad de Dios. Estas realidades objetivas dificultan la fe subjetiva de la persona y hacen que esa fe tenga que superar un serio obstáculo para llegar a ser; y ayudan también a redescubrir un existencial histórico, inherente a la condición humana, que se opone a Dios, con el cual debe contar la persona de derecho en la realización de su fe.

Ante esto ha reaccionado la teología por evidente responsabilidad pastoral y para mantener su identidad como teo-logía. Una consecuencia positiva es que esto ha obligado a la teologia a hacerse más teologal al explicitar al Theos y más radical al volver a sus últimas raices. ${ }^{2}$ La teologia ha llevado a cabo esta tarea, en positivo, desde sus propias raices en la revelación y -unas teologías más que otras - desde los signos de los tiempos. Pero la ha llevado a cabo también de forma dialéctica, tratando de superar lo que considera ser la mayor negación de Dios en el mundo actual y el mayor obstáculo para la fe. Con esto la teologia, en cuanto teo-logia, está recobrando la dimensión dialéctica que, según el Nuevo Testamento, le corresponde, la fe es una victoria, creer es llegar a creer en presencia de la tentación a no creer, tras la serena formulación de la fides quae está la nada pacífica fides qua. Por ello, tanto por lo que toca al contenido de la fe, Dios, como por lo que toca al acto de fe, la teologia se está haciendo teologal también dialécticamente. 
Esta aproximación dialéctica a Dios y a la le ocurre hoy en muchas teologías, y en ello convergen. Pero divergen en lo que consideran ser el polo dialéctico fundamental: ateísmo o idolatria. Indudablemente no hay oposición, sino en principio complementación, entre ambos enfoques; pero sí hay diferencia en elegir metodológicamente uno u otra como aquello que más en directo debe enfrentar la teologia.

En este articulo queremos analizar el significado para la teologia de elegir el ateísmo o la idolatria como el polo dialéctico principal. No tratamos, por lo tanto, en directo de analizar lo que en positivo las diversas teologias dicen sobre Dios - aunque algo de esto es inevitable - sino de analizar el significado de elegir uno u otra. Creemos en efecto que la elección determina el mélodo, talante y contenidos concretos de las diversas teologias; y tras esa elección se esconden diversas visiones del mundo, de la historia y de la fe, en definitiva, diversas visiones de Dios. Las mismas afirmaciones sobre Dios tendrán significados o matices importantes diversos según se vean como superación del ateísmo o de la idolatría. El problema que queremos abordar nos parece, por lo tanto, importante en principio.

Digamos para terminar esta introducción que la finalidad de este artículo quiere ser modesta. Teologia, ateísmo, idolatria, fe y Dios son realidades sumamente complejas cuyo tratamiento adecuado sobrepasa las posibilidades de este artículo. El título, por lo tanio, hay que tomarlo con seriedad. Se trata de "reflexiones" sobre el tema, fragmentarias por necesidad. Pero si ayudan a esclarecer y tomar en serio el problema habrán cumplido su cometido.

\section{La determinación del polo dialéctico: ateísmo o idolatría}

En este apartado queremos describir cómo y por qué diversas teologias determinan su polo dialéctico fundamental. Aunque la distinción no es sencilla, contrapondremos dos tipos de teologias. La primera es la teología del primer mundo, y no es únicamente la que suele hacerse fácticamente en el primer mundo; es la llamada teología progresista. La segunda, la que suele hacerse en el tercer mundo y como teología del tercer mundo; es la llamada teología de la liberación. ${ }^{3}$

\subsection{Atelsmo y teología del primer mundo}

En el primer mundo, el ateísmo, sus diversas manifestaciones (teórica, práctica, positivista, humanista, nihilista) y sus manifestaciones afines (agnosticismo, desinterés por lo divino) son descritos como un signo de los tiempos en el sentido preciso de caracterizar novedosamente una época. Así lo afirmó ya el Vaticano II (GS 19) y lo acaba de reafirmar el sínodo extraordinario de obispos. Ahora se habla incluso de una época postatea, pero no como superación del ateísmo, sino como indiferencia incluso hacia su problemática. Debido al proceso de la Ilustración, y a otras causas que luego se mencionarán, lo que queda claro es que Dios no es ya una obviedad en el primer mundo. La realidad de Dios, lo que formula la fides quae, no esta ya ambientalmente in pos- 
sessione. Así lo afirma e interpreta la teología. "Aunque Dios nunca ha sido una pura evidencia, la siluación en que se produce el discurso sobre Dios cambia radicalmente desde el comienzo de la edad moderna. Si para el hombre religioso Dios o lo divino era la verdadera realidad y el mundo era más bien una realidad aparente o disminuida, para el hombre medio de finales del siglo $\mathbf{X X}$ ocurre a la inversa. Lo evidente es para él la realidad perceptible por los sentidos; la realidad de Dios, en cambio, cae bajo la sospecha de ser un simple reflejo del mundo, una pura ideologia." 4 Esa sospecha ambiental hacia Dios hace que lo formulado en la fides quae deje de ser lo obvio y que también la fides qua tenga que contar con el ateísmo como amenaza permanente desde fuera. "Esta situación se ha generalizado tanto en nuestros dias, que no se trata ya del ateismo de los demás, sino principalmente del ateísmo que anida en el propio corazón." 5

El ateísmo, además, ha sido redescubierto no sólo como amenaza ambiental a la fe, sino como posibilidad para la le debido a la misma realidad de la fe. En su celebrado artículo "La incredulidad como problema teológico," J.B. Metz elevó de derecho el ateísmo a problema estrictamente teológico y no como aquello que sólo debe ser tratado apologéticamente. "La incredulidad concierne inevilablemente al creyente de forma más originaria en su propia realización de la fe y en su propia subjetividad creyente, como incredulidad del creyente, como incredulidad intra nos." 6 La increencia se convierte entonces en un existencial histórico con posibilidades siempre de ser actualizado y con la cual debe contar siempre el creyente.

Tanto por lo que toca a la fides quae como a la fides qua, tanto como fenómeno ambiental de hecho como realidad de derecho, el ateísmo es una realidad sumamente grave para la teología, y así lo ha visto bien la teología en el primer mundo. Su mayor gravedad está sin duda en ser una posibilidad real para la fe por ser un primigenio existencial histórico, pues eso lo hace lógicamente independiente de la realidad ambiental teísta o atea. El tratamiento de este problema es sumamente complejo; supone el tratamiento de todos los contenidos de la fe por una parte, del acto de fe por otra y de la relación entre ambas cosas. Baste decir aquí que el ateismo de derecho impone a la teología un tratamiento de los contenidos teológicos no sólo en relación con la fides quae, sino con la fides qua, exigencia cada vez más sentida y expresada en el urgente deseo de que la teología sea toda ella espiritual, de que sea hecha con espíritu y comunique espíritu, que sea verdadera mystagogia, no sólo esclarecimiento racional, que sea verdadera introducción en el misterio de Dios.?

Pero volvamos al ateismo ambiental, pues éste suele ser considerado como signo de los tiempos y a éste suele tratar de responder la teología progresista. Este ateísmo ha llegado a ser y se ha establecido ambientalmente cuando se ha dado un doble paso: 1) el desenmascaramiento de la realidad de Dios como innecesaria y deshumanizante (ateísmo profético-liberador que establece la irrelevancia y negatividad de Dios para el hombre) y 2) la explicación de la génesis de la idea de Dios a partir de la misma naturaleza humana y sus deseos (ateismo cientifico que establece la no-identidad de Dios). La consecuencia 
seria:" ¿Dios? No es otra cosa que una proyección del hombre (Feuerbach), es opio del pueblo (Marx), un resentimiento de lrustrados (Nieztsche), una ilusión infantil." 8

Este es el ateismo al cual debe enfrentarse la teologia y asi lo han hecho los mejores teólogos. Han tratado de defender a Dios y — cada vez más- de defender al hombre que se deshumaniza sin Dios. Lógica, sino cronológicamente, pueden distinguirse dos grandes etapas en esa defensa de Dios: Dios como posibilidad para la humanización del hombre y Dios como necesidad para su urgente humanización. Por poner ejemplos significativos de la primera etapa, K. Rahner afrontó la aparente disyuntiva entre autonomía del hombre y autonomía de Dios, mostrando que Dios, en cuanto misterio santo, posibilita que el hombre sea hombre y cada vez más humano (en paralelo a la realidad de Dios como misterio) y que en ese llegar a ser más humano hay salvación (en paralelo a la santidad de Dios). Al planteamiento ambiental en forma de disyuntiva, homicidio o deicidio, Rahner opone el de intrinseca relación. Dicho de la forma más radical, "el hombre surge cuando Dios quiere ser no-Dios." 9 W. Pannenberg presenta a un Dios del futuro que puede dar cuenta de toda la realidad y permite y posibilita el que el hombre siga siendo el ser de la esperanza y de la libertad, no coartadas por un Dios que ya estuviese adecuadamente constituido desde el origen. J. Moltmann presenta a un Dios de la promesa y de la cruz, con lo cual el hombre puede seguir siendo el ser de la esperanza, pero viviendo en la realidad histórica y en lo más trágico de ella.

Basten estas citas para mostrar cómo la mejor teologia ha intentado responder al ateísmo defendiendo la verdad y la relevancia de Dios para las posibilidades del hombre. En una segunda etapa, cuando va desapareciendo el optimismo secular surgido de la Ilustración, la teología intenta además mostrar la necesidad de Dios para el primer mundo deshumanizado. Muchas voces se levantan en esa dirección. Se desvanecen las ilusiones prometidas por la Ilustración; más bien "el sueño de la razón engendra monstruos." 10 En lorma gráfica se afirma: "construid un Dios o reconstruid al hombre" (Rostand); y, en forma teológica se dice; "con el misterio de Dios desaparece también el misterio del hombre... La muerte de Dios lleva a la muerte del hombre." ateísmo consecuente lleva al sin sentido y a la deshumanización. Así se afirma también desde los no creyentes. Valgan por muchas unas citas de $\mathbf{M}$. Horkheimer: "Se liquidará lo teológico. Pero con ello desaparece del mundo lo que llamamos "sentido." Ciertamente habrá mucha actividad, pero sin sentido y por ello tediosa." 12 La teologia sigue siendo necesaria como "expresión de un anhelo, un anhelo de que el verdugo no pueda triunfar sobre su víctima inocente... Estoy cada vez más convencido de que no se debiera hablar del anhelo sino del temor a que este Dios no exista." 13

Lo dicho es suficiente para mostrar la realidad del ateísmo y sus consecuencias y explica suficientemente por qué la teología se le enfrente. De hecho asi ocurre, y la teologia progresista eleva a principio este planteamiento al abordar el tema de Dios. El ateísmo es aquello a lo cual debe en directo responder la teología, para ello debe ser "teologia teológica;" 14 siéndolo, será "la única respuesta adecuada al ateísmo moderno" 15 y salvaguardará "la realidad de Dios y del hombre." 16 


\subsection{Idolatría y teologia en el tercer mundo}

En América Latina la situación ambiental es muy distinta. Aun con algunas manifestaciones de ateísmo marxista o positivista, aun con incipientes procesos de secularización, pervive mayoritariamente todavía una religiosidad que no sólo no cuestiona la realidad de Dios, sino que hace de ella la realidad fundamental para la vida toda. Muy notablemente, esta obviedad de Dios no desaparece, sino que pervive y se acrecienta, aunque con excepciones - tendencia que habrá que tener en cuenta- en aquellas comunidades que han tomado conciencia de su realidad oprimida y de las causas - socio-económicas, pero también religiosas - de su opresión; es decir, en comunidades que han pasado por algún tipo de ilustración, más en la línea social que liberal. A pesar de lo predicho por algunas ideologias, esta ilustración, sin embargo, no ha hecho desaparecer la fe en Dios, sino que la ha radicalizado. Como dice un buen conocedor de esas comunidades, "Dios es para ellos un asunto tan concreto y tan identificado con su vida como la experiencia del amor, la experiencia de la lucha... Dios es epidérmico, es la propia experiencia de la vida." 17

Este hecho, sobre todo en la forma de religiosidad popular masiva, pudiera ser analizado y comprendido como un estadio pre-secular que no descualificaria la tesis de la teologia progresista de que el ateismo es el polo dialéctico principal para la teologia. Pero más da que pensar que éste no lo sea para las comunidades y sobre todo que no lo sea para la teologia latinoamericana. Esta, por un lado, es reconocidamente radical y ha incorporado mucha de la crítica de la teología progresista en los análisis históricos, exegéticos, dogmáticos; quiere ser radical también al nivel teologal -aunque no se le quiera reconocer esto con facilidad-, pues sabe muy bien que ninguna teología persiste si no va a sus raíces. $Y$, por otro lado, esa radicalidad teologal no surge del enfrentamiento con el ateísmo descrito. ${ }^{8}$

¿Hay que afirmar entonces que la teologia de la liberación es sumamente radical y crítica en muchos aspectos, pero ingenua por lo que toca a la cuestión de Dios? Afirmar esto seria un grave error de hecho - icómo va a ser ingenua una reo-logía que se lleva a cabo entre la muerte cotidiana de los hijos de Dios y entre sus clamores aparentemente desoidos por Dios? - ${ }^{19}$ y sería un grave error de derecho si se presupusiera que no puede haber tal reo-logía radical si no es en enfrentamiento con el ateísmo. Digámoslo con claridad, también en América Latina hay una "cuestión de Dios," una crisis teologal y un debate teologal, pero todo ello gira primariamente alrededor de la idolatria. Veámoslo, en primer lugar, desde las afirmaciones del magisterio latinoamericano.

Medellín, tras sus documentos sobre la evangelización y la Iglesia, es tambièn una afirmación sobre Dios y, más aún, sobre el problema de Dios en América Latina. Lo primero se nota no tanto en que dedique algún documento a) tema, sino en la ultimidad con que analiza la situación histórica del continente, elevada a signo de los tiempos en sentido estricto -como presencia o ausencia de Dios-, es decir, en su visión teologal de la realidad, visión desde Dios. Lo segundo se nota en cómo analiza en concreto esa realidad histórica, 
realidad que hace en sí misma contra Dios. Esto aparece en los primeros documentos: la pobreza masiva, fruto de la injusticia "clama al cielo" (Justicia, 1), las injustas desigualdades sociales, politicas, economicas y culturales son "un rechazo del Sefior mismo"' (Paz 14; subrayados nuestros). Medellin no usa todavía la nomenclatura de la idolatria, pero expone con fuerza que el dato central de la realidad latinoamericana es gravísimo pecado contra Dios, que es la estricta contradicción de la voluntad de Dios y que ello es fruto del "pecado estructural" (después se le llamará ídolo), el cual es inocultable por las victimas que produce.

También Puebla comienza analizando la realidad del continente de la misma forma. "Comprobamos, pues, como el más devastador y humillante nagelo, la situación de inhumana pobreza en que viven millones de latinoamericanos" (No. 29), lo cual es "contrario al plan del creador" (No. 28, subrayado nuestro). Puebla usa además la terminologia de "ídolo" al denominar a las realidades históricas contrarias a Dios (cfr. nn. 405, 491, 493, 497 y 500). El análisis teológico de la idolatría que hace Puebla no es del todo suficiente, pues se contenta con un análisis transcendental, tal como se hace también en la teología progresista del primer mundo: la negación de Dios lleva a la absolutización de lo creado. Pero, aunque bajo ese aspecto, todo puede convertirse en idolo ("la riqueza, el poder, el Estado, el sexo, el placer o cualquier creación de Dios, incluso su propio ser o su razón humana, No. 491), Puebla menciona en concreto los dos grandes ídolos en la situación latinoamericana: la riqueza (No. 493) y el poder político (No. 500).

En su cuarta carta pastoral 20 Mons. Romero analizó con mayor precisión teológica la idolatria. Recalcó, en primer lugar, su realidad, la existencia de idolos que permean toda la realidad. Por ello, junto a la evangelización positiva, la Iglesia debe desenmascarar a los idolos: éstos son los que hacen contra Dios y los que mutilan y oprimen a los pueblos.

En el análisis teórico de la idolatría, Mons. Romero repite que su posibilidad está en la capacidad de absolutizar lo creado; pero para poder jerarquizar e historizar la capacidad de idolatrización no se contentó con esa afirmación transcendental. Distinguió así entre capacidad subjetiva de absolutizar lo creado y aquello creado concreto que se absolutiza. Distinguió así la idolatría de la riqueza propiedad privada y de la seguridad nacional por una parte y la idolatria de las organizaciones populares por otra. En cuanto absolutizadas, todas estas realidades creadas se convierten en idolos; pero lo que se absolutiza es distinto: fundamentalmente malo lo primero, fundamentalmente bueno lo segundo. Sus consecuencias son distintas, necesaria muerte de las victimas en lo primero, y ambivalentes en lo segundo; positivas, en cuanto mueven a la necesaria justicia, negativas en cuanto fanatizan a sus miembros. El tratamiento de su superación es también distinto: eliminación en el primer caso, humanización en el segundo. Mons. Romero jerarquizó las idolatrias, problema teórico y práctico de suma importancia. Su criterio de jerarquización fue simple: aquello que más atenta contra la realidad de Dios y que por su naturaleza genera otras idolatrias a su servicio. En el caso salvadoreño, como Medellin lo afirma para toda América Latina, el analogatun princeps de la idolatria es la abso- 
lutización de la riqueza-propiedad privada; para Medellín, la injusticia estructural, lo cual es además principio de otras idolatrías al ser en sí misma "violencia institucionalizada" (Paz, 16).

Por último, Mons. Romero analizó la idolatría desde las víctimas, criterio sencillo, pero decisivo para saber si y en qué grado hay ídolos. Estos deshumanizan a quienes les dan culto, pero su maldad más honda se descubre en las víctimas que producen: un mundo de pobres y oprimidos, un mundo de muerte. Esto es lo que muestra que la realidad en sí misma es contraria a Dios y lo que plantea en sí mismo el problema teologal. Existen ídolos que producen muerte y la producen con necesidad - Mons. Romero comparó el ídolo de la seguridad nacional al dios Molok que necesitaba victimas para subsistir-; la misma realidad hace contra Dios y de la forma más violenta y antagónica a la realidad de Dios, produciendo muerte.

Todo lo dicho lo ha conceptualizado la teología de la liberación 21 y desde ahí plantea en qué consiste el problema teologal en América Latina. Existen los ídolos, realidades históricas que fungen como verdaderas divinidades, que reclaman para sí las características de toda divinidad: ultimidad, autojustificación, intocabilidad. Esos ídolos exigen un culto, una praxis y hasta una ortodoxia. En cuanto falsas divinidades no otorgan la salvación que prometen, pues deshumanizan a sus adeptos; pero, sobre todo, producen numerosas víctimas por necesidad. Desde el punto de vista de la fe, estos idolos son contrarios al verdadero Dios. Este ofrece vida y exige propiciarla a los demás, propiciar la vida de los otros, de los pobres, quienes son las víctimas de los ídolos; éstos generan muerte y exigen de sus adeptos el propiciarla.

El problema teologal consiste, entonces, en la existencia de muchas divinidades, las cuales son excluyentes entre sí y están en lucha unas con otras. La superación real de los ídolos es entonces finalidad directa de la teología. El problema para la fe de la persona consiste en tener que elegir entre las divinidades desde su real existencial idolátrico. Finalidad directa de la teología es desenmascarar la existencia de ese existencial, sea cual fuere la autocomprensión de la persona con respecto a Dios, y ayudar a superarlo.

Desde esta perspectiva se comprenderá la lógica interna por la cual la teología del tercer mundo es teología de la liberación y tiene como finalidad la liberación: la liberación histórica de los ídolos y la liberación personal del existencial idolátrico.

\section{3. ¿Ateismo o idolatría?}

Lo dicho muestra la necesidad de que la teología se enfrente con el ateísmo y con la idolatria. La pregunta que hay que hacer ahora es qué es más urgente para la teología y qué la hace más radical y teologal. La respuesta formal es que la teologia debe constituirse a sí misma en la superación de aquello que, según el mismo Dios, es la mayor y la más clara negación de Dios.

Esta respuesta es, como queda dicho, formal y hay que llenarla de contenidos. Al hacerlo, se expresa ya una convicción no sólo teológica, sino de fe, 
con lo cual la argumentación sólo podrá convencer hasta cierto punto. En nuestra opinión, lo que más hace contra Dios hoy es la idolatría, por su masividad, por ser una realidad inequivocamente contra Dios, por ser el signo de los tiempos más flagrante y porque así parece el problema en la Escritura, como se analizará en otro apartado.

Si se aborda el problema de Dios desde las víctimas que produce su negación, no hay duda de que el ateismo ambiental - aunque no necesariamente- ha llevado a la pérdida del sentido de la vida a muchos dubitantes e increyentes. Pero la idolatría sojuzga a un número mayor de seres humanos y conduce a la pérdida de la vida misma. Lo que hemos dicho antes en forma conceptual al hablar de las víctimas de los idolos, digámoslo ahora de forma gráfica. Idolatría significa muerte que impera de mil formas. La muerte lenta que producen estructuras injustas que fría, calculada o al menos, calculablemente generan millones de víctimas; la muerte violenta, rápida y cruel, que sobreviene por necesidad a quienes quieren liberarse de los idolos; las masacres, los genocidios, la desaparición de pueblos indigenas, los conflictos armados, causados por la injusticia, que desangran a los pueblos. Muerte también a otros niveles menos reconocidos, pero reales: la muerte cultural que priva a los pueblos de su autoconciencia y cohesión, la muerte religiosa por la proliferación de sectas alienantes, la muerte tambièn en algunos del sentido ante la impotencia por detener la muerte real, ante la deshumanización de opresores y oprimidos, ante el largo y oscuro túnel de la injusticia.

Esto es lo que en realidad significa idolatria: la muerte de millones de seres humanos, la crucifixión de pueblos enteros. Y la pregunta para la teología es qué le exige esa masiva idolatría. Ya hace muchos años decía H. Assmann: "Si la situación histórica de dependencia y dominación de dos tercios de la humanidad, con sus 30 millones anuales de muertos por hambre y desnutrición, no se convierte en el punto de partida de cualquier teología cristiana hoy, incluso en los países ricos y dominadores, la teologia no sabrá situar y concretizar históricamente sus temas fundamentales." 22 Trece años después, la situación de la humanidad, al menos la del tercer mundo, es todavia más sombría y el futuro se prevé catastrófico. ${ }^{23}$ Cuantitativamente no cabe duda, pues que la humanidad está más masivamente bajo el yugo de la idolatría que bajo el ateismo del primer mundo, y eso lo debe tener en cuenta toda teología.

Cualitativamente suele discutirse, y de hecho se discute, si éste es el hecho teológico más importante, el hecho "mayor" como suele decirse en América Latina. Esta discusión se percibe en la determinación de los signos de los tiempos y en la misma comprensión de lo que significan esos signos. En el primer mundo suele afirmarse con facilidad que el ateismo es el más llamativo signo de los tiempos por lo que toca a la negación de Dios. Pero aqui hay un doble equivoco. En primer lugar, se reduce el significado de signos de los tiempos a aquello que caracteriza a una época - significado pastoral más que teologal de los signos de los tiempos- de acuerdo a Gaudium et Spes 4, y se concluye que el ateísmo es el signo de los tiempos más llamativo. Pero esa conclusión no está probada. Indudablemente el ateísmo es llamativo, pero la idolatría lo es tambièn y más que el ateísmo. Una cosa es que el ateísmo sea llamativo por nove- 
doso y otra cosa es que lo sea más que la idolatria, aunque ésta -desgraciadamente- no sea novedosa. Lo que caracteriza a una época no viene dado sólo ni principalmente por la novedad, sino por la radicalidad del fenómeno. Trágicamente, la idolatría no es nada nuevo -aunque ahora su existencia haya aflorado novedosamente a la conciencia-, pero sigue caracterizando radicalmente a nuestra época. Por esa razón, y aun teniendo en cuenta el significado puramente descriptivo de los signos de los tiempos, no se puede decir sin más que el ateísmo es lo más llamativo. Medellín y Puebla afirman más bien que es la idolatría.

La segunda reflexión es más importante. Si se toma signo de los tiempos en su sentido teologal, como aquello que hace presente a Dios o sus plantes (cfr. GS 11), 一sentido que tiende a ignorar la teología progresista- entonces hay que preguntarse qué es lo que realmente presentiza más a Dios y, a la inversa, qué es lo que niega más a Dios. Desde este punto de vista puede hablarse de una ausencia de Dios en el primer mundo; pero en el tercer mundo existe una positiva contradicción a Dios por la misma realidad de la idolatría. Dios puede estar ausente en la increencia, pero está crucificado en la idolatria. La gran negación de Dios fue el asesinato del Hijo y la gran negación sigue siendo el dar muerte a los hijos de Dios. "Entre tantos signos como siempre se dan, unos llamativos y otros apenas perceptibles, hay en cada tiempo uno que es el principal, a cuya luz deben discernirse e interpretarse todos los demás. Ese signo es siempre el pueblo históricamente crucificado, que junta a su permanencia la siempre distinta forma histórica de su crucifixión. Ese pueblo crucificado es la continuación histórica del siervo de Jahvé, al que el pecado del mundo sigue quitándole toda figura humana, al que los poderes de este mundo siguen despojando de todo, le siguen arrebatando la vida, sobre todo la vida." 24 La idolatría, la muerte del siervo Jesús y la muerte de los pueblos crucificados, siguen siendo de derecho la negación más flagrante de Dios.

La idolatría, además, sigue siendo la negación de Dios más inequivocamente clara que el aleísmo histórico (a no ser que por definición se defina el ateismo como inequívoca negación de Dios, lo cual no admite hoy la teologia moderna). Sin minimizar en absoluto el problema del ateísmo y sus consecuencias deshumanizantes, éste no tiene por qué ser pecado, mientras que la idolatria es por definición $y$ por sus consecuencias visibles inequivocamente negación de Dios. De esto debe ser muy consciente la teología. Cuando la teología pretende constituirse ante el ateismo se enfrenta a una realidad socio-cultural posible y probablemente deshumanizante, pero desde la idolatría se enfrenta a una creación de Dios fracasada, crucificada; desde el ateísmo se enfrenta con un ambiente que niega o prescinde de Dios, desde la idolatria se enfrenta con una realidad que hace contra Dios; desde el ateísmo se enfrenta al existencial histórico de la increencia que puede llevar a la absolutización de lo creado, desde la idolatria se enfrenta al existencial idolátrico realizado que da muerte; desde el ateismo se enfrenta a la posible pecaminosidad del hombre, desde la idolatría se enfrenta con el pecado real. En resumen, para la teología el ateísmo presenta la ambiguledad de poder ser pecado subjetivo y cristalizar en pecado objetivado; la idolatria es pecado objetivado donde cristaliza el pecado subjetivo.25 
La idolatria nos parece ser, pues, la mayor y más inequívoca forma de negación de Dios, y nos parece ser también la forma con que se describe más radicalmente el existencial histórico de todo hombre de negar a Dios. ${ }^{26}$ Así lo afirmó ya poco después de Medellin, Juan L. Segundo. "Nuestra reflexión comienza interesándose mucho más en la antítesis - aparentemente fuera de moda-fe-idolatria que en la -aparentemente actual-fe-atelsmo." 27 Y la razón es que en lo primero el hombre se confronta más radicalmente consigo mismo, tiene que decidir si en el Tondo quiere ser dominador o servicial, lo cual en principio puede coexistir con una autocomprensión creyente o atea. "Creemos que divide más profundamente a los hombres la imagen que se hacen de Dios que el decidir luego si algo real corresponde o no a esa imagen." 28

Por todo lo dicho, la idolatría nos parece un problema más universal y urgente para la teologia que el ateísmo como punto de partida. Lo es evidentemente para el tercer mundo; pero debería serlo también, creemos, para el primer mundo. Indudablemente en éste se tendrá que dar una respuesta al ateísmo por obvias razones pastorales. Pero esto no quita que la teología del primer mundo no deba enfrentarse seriamente con la idolatría. En primer lugar, porque ésta posee una dimensión mundial que atañe a toda teología y a la de los países del primer mundo corresponsables en su generación. Y en segundo lugar porque no hay que descartar la hipótesis, muchas veces comprobada en la actualidad, de que en la respuesta a la idolatría se pueda encontrar una solución, indirecta pero eficaz, al ateísmo del primer mundo.

Pero el enfrentarse con la idolatría es importante también para la misma teología y es más fructífero que enfrentarse con el ateísmo. Esto es lo que queremos mostrar a continuación analizando la teología constituida desde el ateismo o desde la idolatría como polo dialéctico principal. La intención de este análisis es mostrar que la teología progresista tiene más limitaciones de las que se piensa y la teologia de la liberación ofrece más posibilidades que las que se le conceden al tratar el tema de Dios. El análisis no of rece, por lo tanto, una evaluación total de ambas teologias, sino que trata de esclarecer lo que está en juego al enfrentar el ateismo o la idolatría y las posibilidades de ambas cosas para la teologia.

\section{Limitaciones de una teología constituida unilateralmente en el enfrentamiento con el ateísmo}

La teologia constituida en diálogo con la ilustración y para superar el ateísmo proveniente de ella ha logrado buenos frutos. Recordémoslos brevemente: la purificación de la imagen de Dios con la superación de antropomorfismos y supersticiones, el énfasis en la realidad históricamente salvífica de Dios al tener que mostrarlo como posibilitador de la autonomía y libertad humanas, la recuperación de la creaturidad teologal, de la solidaridad con la condición teologal humana, al no poder argumentar ya sólo dogmática o autoritativamente, y la profundización en la realidad de Dios como misterio.

Sin embargo, el enfrentarse unilateralmente con el ateismo proveniente de la ilustración ha supuesto también limitaciones e incluso aporias para ese tipo de teologia que hemos llamado progresisla. 


\subsection{Aceptación poco crítica del planteamiento crítico: teología poco profética}

Toda ilustración, descle los griegos, es critica con respecto a la imagen de Dios y al origen de esa imagen en el mismo hombre. Una teología que se conslituye en diálogo con la Ilustración tiene a su vez que ser critica y dejar de ser ingenua, con los resultados positivos apuntados. Pero esa crítica necesita, a su vez, ser criticada.

Lo que llama la atención desde el tercer mundo no es la dimensión crítica de la teología, sino el que se carguen tanto las tintas en su objeto, Dios, y tan poco en el sujeto; cosa tanto más sorprendente cuanto, como ya hemos visto, el resultado de esa crítica a Dios no ha humanizado al sujeto. Sorprende también que se siga insistiendo en la necesidad de volver a Dios, "la vuelta a lo sagrado," sin criticar los presupuestos que hacen a Dios ausente del primer mundo. Veamos brevemente la critica teológica al sujeto.

Como es sabido, cuando la teologia se enfrenta a Dios en la linea de la teología natural, se recalca la radical discontinuidad entre Dios y hombre; y, al nivel de la fe, el necesario sacrificium intellectus. Se suele añadir incluso que en la situación histórica del hombre para que conozca a Dios son necesarias algunas actividades, como la de la humildad, etc. Con esto se recalca que el sujeto no puede fácilmente llegar a conocer su objeto; se hablará, por lo tanto, de la limitación del sujeto para conocer a Dios. Pero, en este enfoque, no hay propiamente una crítica al sujeto para que pueda llegar a conocer a Dios. El hombre es quien pregunta por Dios, el hombre es quien critica las imágenes que se va formando de Dios; pero no aparece que el hombre tenga que ser preguntado y criticado él mismo para llegar a conocer a Dios.

Como es sabido también, ha sido la teologia protestante la que ha rechazado este esquema formal del conocimiento de Dios. Así lo afirmó radicalmente K. Barth, Dios es la crítica del hombre y no a la inversa. Así lo dijo, de formás moderada, Bulımann: para el conocimiento de Dios se necesita un punto de enlace y un punto de contradicción (Anknüpfung und Widerspruch). J. Moltmann lo ha vuelto a repetir en la coyuntura de la teología contemporánea: "La modernidad ha convertido al hombre en palabra iconoclasta contra las imágenes religiosas de Dios. Pero esto sólo sigue teniendo sentido mientras, inversamente, al Dios auténtico se lo convierta en palabra iconoclasta contra el hombre." 29

La crítica al sujeto ha sido, pues incorporada al planteamiento teologal: mientras no se opere algún tipo de conversión en el sujeto, no se podrá conocer a Dios. La superación del aleismo supone algún tipo de conversión porque - ya se sabe desde la fe-Dios es también critico hacia el hombre.

Pero la teología progresista opera la crítica al sujeto individual y no al sujeto social, expresión de una determinada sociedad. ${ }^{30}$ Insiste en que el lugar de plantear y resolver el problema de Dios es la persona, pero ignora eficazmente que esa persona vive en una determinada sociedad. No aparece la sospecha de que la sociedad, no sólo en su cultura ambiental, sino en su realidad socio-politico-económica es una realidad que hace contra Dios; en el lenguaje 
anterior, que es un idolo. Más en concreto, las sociedades donde se hace la teología progresista son sociedades occidentales, capitalistas, basadas en la dominación de unos por otros, dominación que podrá aparecer a veces de forma sutil y a veces de forma burda, sobre todo cuando se considera la dominación de unos países por otros. Se reconocen, por supuesto, las limitaciones de esas sociedades, pero no se admite seriamente la sospecha de que sean idolos: el teologumenon de la "reserva escatológica" relativiza la sociedad, pero no la crítica con vigor. No hay entonces crítica social teológica, aunque otros ideólogos la hagan, ni se ve ésta como una necesidad de derecho al plantearse el problema de Dios, en analogia, al menos, con la necesidad de la crítica al individuo. No se sospecha que Dios puede ser la critica no sólo del individuo, sino de la sociedad como tal, sospecha necesaria al menos para una teología que desea ser bíblica.

Lo que ocurre entonces es que el diagnóstico sobre las causas del ateísmo es limitado y puede ser erróneo en lo fundamental. Al menos hoy, a diferencia de lo que pudo ocurrir hace siglos en los comienzos de la Ilustración, no es sólo el ambiente cultural, lo que explica el ateismo y lo que hay que combatir, sino que es también la misma realidad social la que está estructurada no según Dios, sino en contra de la realidad de Dios, según el principio de la dominación. Lo ambiental no es entonces sólo la negación o el prescindir de Dios, sino lo que hace contra Dios. Y de ahi la consecuencia: "El cristiano no encuentra en la experiencia de su vida social ningún elemento que le sirva para pensar al Dios que se reveló en Jesucristo." 31

No basta, por lo tanto, la crítica al ateísmo ambiental cultural ni la crítica al sujeto individual, sino que hay que avanzar a la crítica teológica de la sociedad. Si se descubre que ella es en sí misma ídolo, entonces, se comprenderán mejor las raices actuales del ateismo. El ídolo deshumaniza a sus adeptos, y esto es lo que recalca la teología progresista al mostrar el sin sentido en que viven tantos seres humanos. Pero su limitación consiste en querer combatir estas consecuencias y presentar a Dios en directo como quien otorga sentido, sin caer en la cuenta de la necesidad de erradicar el ídolo, por lo menos de criticarlo. Y para ello es absolutamente necesario que la teología vuelva sus ojos y se vuelque hacia las víctimas directas del ídolo, en el primer y tercer mundo.

La teología progresista debe, por lo tanto, ser consecuentemente crítica, avanzar a la critica de la sociedad, pero como crítica teológica. El hacerlo no garantiza, por supuesto, la automática superación del ateísmo, pero significa desenmascarar al menos una realidad que es en sí misma anti-divina y que puede ser la raiz más honda de la ausencia ambiental de Dios. Dicho biblicamente, la teología debe hacerse consecuentemente profética, crítica de los ídolos, porque sabe -además- que Dios es precisamente la crítica de esos idolos, no solo de los individuos. "Lo extraño es que se acepte prácticamente sin crítica esa falta de crítica del hombre de la civilización industrial, cuando se trata del problema de Dios, siendo asi que una gran parte del mensaje de ese mismo Dios consistió en denunciar las estructuras humanas fundamentales que conducirian, más tarde, a esa mutilación." 32 Criticar la ausencia ambien- 
tal cultural de Dios sin criticar la negación que se hace de Dios en la misma realidad social es histórica y biblicamente inadecuado y pastoralmente -asi parece- ineficaz.

\subsection{Insuficiente ultimidad teológica: teología poco práctica}

Para la fe y para la teologia el ateismo es un error, pero no es necesariamente pecado, a no ser que se lo defina de tal manera que lo sea por definición, pero esto no ocurre cuando la teologia se enfrenta al ateísmo contemporáneo. En términos operativos esto quiere decir que un ateo se puede salvar; y -si no se tiene una concepción extrinsecista de la salvación- quiere decir que puede vivir ya como salvado. Lo último, por lo tanto, no hay que buscarlo en la explicitación que el hombre se hace de sí mismo como creyente o ateo sino en otra cosa.

La Escritura, más interesada en verificar si hay fe que en definirla conceptualmente, busca siempre un criterio de verificación que no es el de la propia autocomprensión. La ultimidad del ser humano y su salvación se deciden a otros niveles: en la toma de postura ante el necesitado (Marcos), en el hacer la voluntad de Dios (Mateo), en comportarse como cl samaritano (Lucas), en practicar la verdadera religión: visitar huérfanos y viudas (Santiago), en el amor al hermano y en el mayor amor de dar la vida (Juan).

Estas alirmaciones son de sobra conocidas, pero representan una aporia para una teología que pretenda constituirse en ultimidad, enfrentándose sólo con el ateísmo. Asi lo han visto, además, los teólogos europeos confrontados con el hecho masivo del ateísmo y de la fe amenazada. Para interpretar y evaluar correctamente el ateismo y la fe desde un punto de vista estrictamente teológico, han tenido que ir más allá del ateismo y la creencia. Así lo hizo K. Rahner desde el análisis del ateismo con su formulación de la posibilidad de los cristianos anónimos. Pero lo importante es su fundamentación. "Alguien puede tenerse a sí mismo por ateísta, cuando, en realidad, en su incondicional sumisión a la exigencia de lo ético (si de verdad se somete; lo cual, por otra parte, no implica necesariamente que desde el prisma burgués sea un "hombre bueno'), él afirma a Dios y en la profundidad de su conciencia sabe que lo hace, aunque en aquella esfera mental donde trabaja con conceptos objetivos interprete Calsamente lo que de hecho realiza." 33 Y asi lo hizo J. B. Metz desde el análisis de la fe. "La conciencia, en la que su fe libre se conoce a sí misma, presenta por eso una zona de oscuridad en sí; no es un saber en el que el creyente podria volver con dominio sobre sí mismo, sino en cierto modo un saber pre-reflexivo, y la verdad de ese saber no se revela al creyente si éste mira hacia sí mismo y a su propia subjetividad, sino sólo si se pierde a si mismo en el impulso de una nueva perfección; si, en una palabra, "hace la verdad" (cfr. Jn.3.21)" 34 (subrayado en el texto).

Sea desde el análisis del ateismo o de la creencia, se afirma aquí que la ultimidad del hombre no está en la autocomprensión categorial de sí mismo, sino en otra cosa: en la incondicional sumisión a la exigencia de lo ético, en el hacer la verdad. Puede preguntarse si a este nivel aparece ya con absoluta claridad la 
ultimidad del hombre; y la respuesta tampoco es afirmativa, pues eso en definitiva pertenece a su último misterio, y ya Trento avisaba que nadie sabe si vive en gracia o no. Históricamente además, siempre se podrá discutir si un hombre está siendo fiel a su conciencia o haciendo la verdad (como lo muestra el gráfico ejemplo que pone K. Rahner). Pero sí se declara que la ultimidad del hombre se expresa más en lo que hace que en lo que piensa de si mismo. Eso es también lo que afirma la Escritura en pasajes programáticos. Hoy se repite que la relación del hombre con Dios no está adecuadamente descrita por el lenguaje de "conocer" o "no conocer," sino por el de "re-conocer" o "des-conocer", pero el paso de uno a otro no depende sólo ni fundamentalmente del conocer. Lo que sea re-conocimiento de Dios ya se ha ilustrado antes con algunas citas. Lo que es el des-conocimiento de Dios viene dado en Romanos 1,18ss: el acto primigenio de "reprimir con injusticias la verdad." En Juan 3,19 las malas acciones son las que no dejan ver la luz que viene al mundo.

Lo que esto significa para la teologia es que no puede contentarse con la iluminación de lo que es la fe, sino que debe iluminar las obras. Esto es lo que en el fondo se quiere decir cuando se afirma que la teología debe ser práxica. No se trata aquí sólo de ética ni, por supuesto, de sociología y política. Se trata de una dimensión primigenia de una teología teologal: iluminar, propiciar las obras que llevan al re-conocimiento de Dios. Si se quiere, se trata de que la teología se comprenda y se realice no sólo como intellectus fidei, sino como inrellectus amoris, que recalque no sólo la alteridad con respecto a Dios, a la cual hay que responder con fe, sino también la afinidad con respecto a Dios en la realización de las "buenas obras."

La teología progresista no ignora por principio esto último, por supuesto. Pero se concentra y a veces se reduce a mostrar el intellectus fidei para posibilitar la superación del ateismo. Pero con esto no alcanza ni la ultimidad del hombre ni la de Dios, hasta que no avance a las obras en las cuales el conocimiento de Dios se convierte en re-conocimiento o en des-conocimiento. Y además, no alcanza ultimidad pastoral. Es sabido que ya el Vaticano II (GS 19-21) afirmó que el ateísmo del primer mundo es un fenómeno históricamente derivado. Sus causas están en la crítica externa a lo religioso y en el comportamiento (interno a la fe) de los propios creyentes. La responsabilidad de los creyentes viene expresada en una doble línea: una presentación inadecuada de la verdad de lo que creen y el defectuoso comportamiento religioso, moral y social. De ahi que los remedios sean una exposición adecuada de la doctrina y "manifestar la fecundidad de la fe imbuyendo toda la vida, incluso la profana, de los creyentes, e impulsándolos a la justicia y al amor, sobre todo respecto del necesitado" (GS 21).

Estas propuestas son pastorales, pero imponen también tareas teóricas para la teologia. Hay que esclarecer la verdad de la fe, pero hay que manifestar la fecundidad de la fe. Por ello, la teologia debe ser también práxica por razones pastorales y por la específica razón pastoral de responsabilidad ante el ateísmo. ${ }^{35}$ 


\subsection{Excesiva transcendentalización a costa de la concreción de Dios: teología poco "evangélica"}

Todo fenómeno de ilustración tiende a combatir el antropomorfismo a nivel conceptual y la superstición a nivel práxico con respecto a Dios. Se critica a un Dios funcional, tanto al nivel de explicación como de transformación de la realidad. La teología que se constituye en el enfrentamiento con el ateísmo asume esa crítica. La asume en lo que tiene de verdad; pero la asume también, y con radicalidad, para poder defender a Dios ante los ataques de antropomorfismo y superstición. La consecuencia positiva es la revalorización de la transcendencia de Dios, del misterio de Dios.

La insistencia en la transcendencia de Dios es necesaria; pero para una teologia cristiana no es suficiente y además es peligrosa. La teología cristiana tiene que mantener primigeniamente tanto la transcendencia de Dios como su concreción; tiene que afirmar que el Padre de Jesús es "Dios," pero tiene que afirmar con la misma originariedad que Dios es en concreto el "Padre." En la conocida definición de $\mathbf{K}$. Rahner, Dios es "misterio santo," y ambas cosas hay que mantener para confesar al Dios de Jesús.

Pues bien. Para defender a Dios ante la crítica de la Ilustración, la teologia tiende a enfatizar su transcendencia. Para superar el antropomorfismo se sabrá de Dios un mínimo; para superar la superstición se hará de Dios el no afectable por el mundo y el que no afecta al mundo. "La Ilustración, desde la imposibilidad del hombre para manejar a Dios, va a concluir en la distancia infinita y la incapacidad de Dios para ser afectado por el hombre y el mundo." 36

Las consecuencias de este movimiento del pensamiento son conocidas. Al nivel de antropologia, ya desde Aristóteles, existe una correlación entre imagen ilustrada de Dios y autocomprensión del hombre. Al Dios ilustrado de Aristóteles, el Dios inafectable, corresponde un hombre autosuficiente, cuya máxima perfección estará en la contemplación, no en la amistad o el amor que supone afectabilidad y dependencia (aunque para que pueda existir el tal hombre contemplativo se necesita una sociedad de esclavos). Al Dios sin entrañas corresponde un hombre sin entrañas. José I. González Faus lo ha dicho de manera gráfica, quizás de forma exagerada y unilateral, pero no irreal. "Lo calamitoso de la imagen ilustrada de Dios es que, a la larga, la idea de Dios acaba siempre siendo - para aquellos que la afirman - el norte de la idea del hombre. Y de ese Dios apático, inafectado, sin amigos, se pasa a una concepción de la perfección como pura autarquía. Bastarse a sí mismo, no necesitar de nada ni de nadie, no tener amigos, no dejarse sacudir emotivamente, vivir en un olimpo económico y en un olimpo cultural donde el dolor no tiene entrada ni acceso... todo eso serán los componentes de la idea del hombre para los ilustrados creyentes. Y esos componentes son los que han engendrado el monstruo de inhumanidad que es el mundo del siglo XX." 37

Pero tiene consecuencias también para la teo-logia. Indudablemente, toda teologia, en cuanto cristiana, tiene en cuenta no sólo la transcendencia, sino la realidad concreta de Dios. Pero al obsesionarse, digámoslo asi, con el peligro que representa la llustración, lo concreto de Dios puede llegar demasiado tarde o sin suficiente concreción especifica. 
Por mucho que la teologia deba superar los antropomorfismos no puede ignorar el antropomorfismo fundamental y fundante de la revelación de Dios y de la fe cristiana: la "forma del hombre" Jesús de Nazaret. En la teologia actual se ha superado formal y conceptualmente el docetismo; se toma en serio la naturaleza humana de Cristo y se avanza para comprenderla históricamente como la realidad de Jesús de Nazaret. Pero esto no indica que no queden importantes resabios - prácticos más que teóricos- de docetismo. Se insiste hoy en lo fundamental del reino de Dios, en el mensaje de Jesús, pero se avisa con insistencia en no caer en la tentación de regionalizar el reino, en la provisionalidad que impone la reserva escatológica a toda forma histórica que quisiera equipararse con el reino. Se presenta la vida de Jesús de Nazaret, pero no infrecuentemente su actividad es comprendida a un nivel religioso-histórico, pero no religioso-político; sus bienaventuranzas se dirigen a pobres en general, pero no a pobres reales, y sus maldiciones son con frecuencia pasadas por alto. Todavia hay algunas presentaciones de su resurrección que no toman muy en cuenta la cruz; y presentaciones de su cruz que no analizan sus causas históricas. Se presentan las exigencias de Jesús, pero no se hace del seguimiento algo central. 38

Con todo esto queremos decir que sigue perviviendo una tendencia, más o menos realizada, a afirmar, sí, lo concreto de la revelación de Dios en Jesús, pero no a hacerla absolutamente central, tan central como el Dios transcendente que se manifesta en Jesús. Todavia sigue presuponiéndose que la gran dificultad para la fe es aceptar la transcendencia presente en el hombre Jesús y no tanto lo concreto de esa transcendencia. Al nivel del lenguaje, se nota en la obvia aceptación del antropomorfismo del "Dios mayor" y en la no tan obvia aceptación del otro antropomorfismo del "Dios menor."

Por lo que toca a la superstición, a la afectabilidad de Dios, de nuevo se ha superado ya la comprensión a-pática de Dios al nivel formal. Pero, como dice gráficamente J. Vives, la mente ilustrada le teme a un "Dios islámico" 39 y prefiere ver la funcionalidad de Dios en sus actuaciones transcendentes en el origen y en el final, en la protología y la escatología, o en sus relaciones personales con los hombres, pero no sabe qué hacer con un Dios demasido presente en este mundo, denunciando injusticias, defendiendo a huérfanos y viudas, alentando procesos de liberación. Y esto se nota de manera muy clara en que la teología progresista es muy reacia a admitir que haya signos de los tiempos donde se muestre la presencia o la ausencia de Dios. El que Dios sea hoy afectado, el que hoy reaccione en este mundo, el que hoy los hombres puedan contar con Dios, parece algo demasiado concreto y peligroso. Todo ello habrá que afirmarlo del pasado, de la historia de la revelación de Dios en la Escritura, pero para el presente sonaría a antropomorfismo y superstición; por ello mejor es concentrarse hoy en la transcendencia de Dios. Pero hay que preguntarse si el más grave antropomorfismo y superstición no consiste precisamente en que el hombre decida por cuenta propia si, cuándo y cómo se ha de manifestar Dios.

Lo que nos parece estar en el fondo de estas dificultades es lo siguiente: ante la crítica de la Ilustración la teologia intenta mostrar a Dios como "ver- 
dad;" pero, puesta a la defensiva, no recalca con la misma originariedad que es "buena noticia." De nuevo, puede existir aquí el temor de que al presentar a Dios así la teologia se exponga otra vez a la crítica de que Dios es una proyección de los deseos del hombre. Pero hay que ser muy conscientes de que si Dios no es presentado primigeniamente como buena noticia no se está hablando del Dios cristiano.

Cuáles son las razones para la dificultad o incapacidad de hablar de Dios como buena noticia es cosa a analizar. En el primer mundo hay desencanto, la Ilustración no ha producido lo que prometía, los progresos, si los hay, son más cuantitativos que cualitativos, la expectativa de una buena noticia se desvanece, por lo tanto, ambientalmente. Además una buena noticia tiene como caracteristica esencial el ser don, supone la actitud de dejarse dar, dejarse sorprender $y$, correlativamente, la actitud de agradecer; $y$ todo ello al nivel de antropología fundamental.

Si esto es asi, es comprensible que a la teología le cueste presentar a Dios como buena noticia; pero debe ser al menos consciente de dónde está la dificultad y cómo superarla. Una teología puramente argumentativa, en el fondo, de la verdad de Dios no genera la aceptación del contenido concreto de esa verdad: el ser buena noticia. Para generarla hay que hacer teologia "evangélicamente," es decir, no sólo presentando los contenidos de los evangelios (y de toda la Escritura), sino con talante evangélico, con la convicción y el gozo de estar of reciendo una buena noticia. Y, por otra parte, dirigiéndose al hombre no sólo en su capacidad de aceptar razonable y controladoramente la verdad de Dios - incluso cuando el hombre acepta la incontrolabilidad de Dios por ser una realidad transcendente, está en control al menos de esa incontrolabilidad - sino al hombre en su dimensión antropológica de dejarse dar y de agradecimiento.

En el fondo esto supone una argumentación sobre Dios desde la fe realizada; pero no sólo desde una fe que ha superado el ateísmo ambiental, sino desde una fe que ha acogido a Dios como buena noticia. Y ello lleva a la pregunta ineludible por el lugar dónde ambientalmente puede haber una fe asi. Tanto desde la Escritura como desde la historia actual, ese lugar son los pobres de este mundo. ${ }^{40}$ La buena noticia del concreto Dios de Jesucristo es correlativa a los pobres. En ese lugar puede haber fe y la concreta fe en el Dios de Jesucristo. La teología debe hacerse, por lo tanto, desde ahi; y desde ahi puede argumentar con la le realizada. La teología podrá entonces argumentar sobre la verdad de Dios, pero desde una verdad-buena noticia a simullaneo. Desdoblar verdad y buena noticia, querer asegurar lo primero para ofrecer después lo segundo es metodológicamente arriesgado y pastoralmente parece ineficaz. La teología tiene que ser, pues, constitutivamente evangélica y tiene que preguntarse por ello por sus condiciones de posibilidad con tanta seriedad como con la que se pregunta por su condición de posibilidad de constituirse simplemente en reo-logia. Pero para ello debe volver al lugar original de la buena noticia: los pobres de este mundo. 


\subsection{Incorrecta universalizaclón de la teologia: teología poco universal}

La teologia que se constituye enfrentándose al ateismo presupone, aunque no lo pruebe, que ése es el enfoque más universal para debatir el problema teologal. Con loda naturalidad se habla, por ejemplo, de "la cuestión de Dios hoy," 41 cuando de hecho se analiza esa cuestión desde y para un determinado grupo de seres humanos. Se adecúa sin más al hombre con"el hombre medio del siglo XX."42 Indudablemente esas teologias saben muy bien que empíricamente las cosas no son así, que en la humanidad ese hombre es minoria. Pero aunque - se supone- aceptan ese hecho, siguen elaborando la cuestión de Dios, como si así fuese de derecho, desde el ateismo. De esta forma y en buena lógica, cualquier otra forma de enfrentar el debate teologal sólo tendria sentido como estadio pre-secular del debate y bajo la hipótesis de que se llegará a enfrentarlo desde el ateismo. Hay aquí una advertencia, si se quiere, importante. Pero el presupuesto y la hipótesis se aceptan sin crítica y sin la sospecha siquiera de que enfrentar el debate teologal de otra manera -desde la idolatria - tiene también como finalidad el que no tenga que ser enfrentado desde el ateismo masivo.

La teología progresista se universaliza, pues, a si misma, lo cual lleva a ignorar otras o a comprenderlas desde su propios presupuestos. En el citado libro de Kasper, por ejemplo, se menciona la leologia de la liberación de pasada y conjuntamente con la teologia política europea, con lo cual -además del desconocimiento de la diferencia entre ambas - no se sabe exactamente qué se dice de la teología de la liberación. El juicio sobre ella ( $y / 0$ sobre la teología política) es negativo: "cabe preguntarse si esta teología no es víctima, a su vez de reducciones más funestas." 43 Pero lo importante no es ahora el juicio sobre la teologia de la liberación; lo importante es el presupuesto, que cualquier teologia que se enfrente con el problema de Dios tenga que hacerlo para responder al ateísmo. De esa forma se ignora el planteamiento específico de la teología de la liberación y se la reduce para que pueda ser incluida en el planteamiento de la teología progresista.

Esta tendencia autouniversalizante no desaparece cuando en publicaciones más recientes se incluye el tema de la idolatría en la cuestión de Dios. En el libro de Kasper, por ejemplo, se mencionan los idolos varias veces (pp.68, $129,157,185,259,274)$. El término se ha recuperado, pero no creemos que la realidad tras el término se haya hecho central. Pero antes de analizar este problema, hagamos un breve recordatorio sumamente importante.

La teología progresista ha hablado mucho del ateismo y prácticamente nada de la idolatría, al menos en el sentido explicado en el primer apartado. Incluso la teologia biblica, que no puede menos de enfrentarse con el tema, ha ignorado su significado como problema sistemático que pudiera esclarecer la cuestión de Dios en la actualidad, como se afirma en un libro reciente sobre los profetas de Israel que lleva el significativo título Los dioses olvidados. ${ }^{44}$

El por qué de ese olvido puede estar en el presupuesto ingenuo de que la idolatria se expresa fundamentalmente a nivel religioso y no seria por ello problema en las sociedades del primer mundo. De ahí también que en la exége- 
sis, como se dice en el libro citado. "La idolatria se estudia casi siempre desde esta doble perspectiva: el uso de las imágenes en el culto yahvista y el culto a los dioses paganos. Enfoque estrictamente cultual, centrado en la problemática de hace muchos siglos." 45 Pero ese presupuesto es llamativo precisamente en una teologia que ha secularizado sanamente lo religioso en positivo, pero que no ha sospechado que también lo religioso se puede secularizar en negativo, es decir, que haya un idolatría secular, como ya lo hicieron los profetas, según G. von Rad, ${ }^{46}$ al secularizar también el primer mandamiento.

Ese olvido corre paralelo al olvido de otros grandes temas bíblicos, como el de la liberación, los pobres, etc., y es, por lo tanto, un olvido esencial. El hecho como tal ya lo hemos desenmascarado antes al analizar la falta de crítica teológica al ídolo social; y la razón última podría estar en el temor de descubrir que hoy también el problema fundamental sigue siendo la idolatria que produce millones de víctimas.

Como deciamos antes, hoy se ha recuperado el término de la idolatria y se afirma incluso que su problemática es también actual (p.68). Pero, con todo, el planteamiento dominante no es desde la idolatría.

El problema fundamental a tratar y a responder sigue siendo "la cuestión del sentido del ser" (p. 65), la "secularización" (p. 18), la "praxis que prescinde de su fundamentación transcendente" (p. 18), la dificultad del lenguaje sobre Dios (p. 68). La finalidad de la teología sigue siendo mosırar "la idea de Dios como fundamento y mela de toda realidad" (p. 23), posibilitar "la liberlad del hombre y salvar la trascendencia de la persona humana (p. 185). Todas estas cuestiones son, por supuesto, muy importantes, pero muestran que el planteamiento teologal sigue siendo desde el ateísmo y no desde la idolatria aunque se la mencione.

Lo que ocurre entonces es que se menciona la idolatria, pero se la subsume de hecho en el ateísmo, en un análisis puramente conceptual: la verdadera negación de Dios es ipso facto absolutación de lo creado lo cual, en sí mismo, produce víctimas. Pero esta afirmación transcendental permanece estéril si no se la analiza un minimo. Desde un punıo de vista sistemático hay que preguntarse qué es más primigenio o, al menos, si dos cosas ocurren a simultaneo: la negación de Dios y las obras idolátricas; hay que preguntarse qué es lo que verifica a qué, si el ateísmo a la idolatría o la idolatría al ateismo. Desde un punto de vista hisı́rico es una ligereza contentarse con la afirmación transcendenıal y no analizar las diversas idolatrias, jerarquizarlas, pregunıarse al menos si no existe un analogatum princeps entre ellas; y es sobre todo irresponsable no analizar las víctimas de la idolatria, su masividad, su crueldad, etc. Con esto queremos decir que asumir el término idolatria en el problema de Dios, pero analizarla sólo como el reverso conceptual del alcismo, no significa que una teologia ya ha integrado la idolatría en su planteamiento de Dios. La ha subsumido más bien en el ateismo y éste sigue siendo el polo dialéctico principal. Nos parece que esto es lo que ocurre en algunas teologias y en el documenlo del sinodo extraordinario: el ateismo sigue siendo el enfoque más universal para tratar el problema de Dios. 
Esta pretensión universal de derecho de la teología progresista es altamente llamativa. Lo es desde un punto de vista pastoral cuando sus resultados han sido más bien escasos en la superación del ateísmo. Lo es desde un punto de vista puramente lógico, pues no se entiende por qué una teologia que precisamente recalca tanto la transcendencia de Dios no está abierta a otros puntos de parlida que, asintóticamente, pudieran plantear mejor el problema y resolverlo. Lo es, por último, desde un punto de visıa ideológico. Digámoslo con claridad. Este tipo de teología da la sensación de autocomprenderse ella misma como el centro de la teologia correlativamente a lá autocomprensión del primer mundo como el centro del mundo; da la sensación de querer mantener como paradigmálicos sus mélodos y contenidos para 1oda teología. Dicho crudamente, da la sensación de que la verdad y la verdad de Dios tiene que pasar ante todo por el primer mundo para desde ahi exlenderse a otros mundos (análogamente a como se entienden las inslancias eclesiales). Y lo más chocante es que incluso cuando la realidad de Dios se ha tornado altamente problemática en ese mundo, ese tipo de teología pretende mantener la exclusividad al menos del problema de Dios, de modo que su problema tenga que ser el problema de Dios. Y si en ese mundo existe un ambiental silencio de Dios, en lugar de autocriticarse y preguntarse seriamente por qué, se eleva cse silencio a problemática universal.

Afortunadamente, también en el primer mundo se ven las cosas de diferente manera. "El Dios verdadero nos liene ya muy acostumbrados a llegar por los caminos donde menos se le espera." 47 Y si de universalidad se trata, también desde el primer mundo se está redescubriendo una más verdadera unjversalidad. "Hoy como siempre, Dios viene desde la marginalidad, desde la periferia de la hisioria humana, desde los pobres y oprimidos." 48

\section{Posibilidades de una teología que se constiluye ante la idolatría}

Todo lo dicho en el apartado anterior hay que entenderlo bien. No se niega que la teologia pueda y debe enfrentarse con el ateismo, no se niega que eso haya producido frutos muy positivos, no se niega que eso haya sido necesario cuando la Ilusiración y sus macsiros de la sospecha pusieron en serios aprietos a la teologia y a la fe. Pero se quiere insistir en que ese lipo de teología tiene también sus limitaciones, que no debe pensarse a si misma como la más radical teo-lógicamente por haberse enfrentado al ateísmo y por ello la más universal; y se quiere insistir sobre todo en que en este final del siglo $\mathrm{XX}$, en que la humanidad se ha hecho más consciente de la idolatria -en el tercer mundo es evidente y en el primer mundo hay suficientes elementos para llegar a esa conciencia-, ésta tiene que ser tratada al menos con la misma seriedad que el ateismo y, por lo que antes hemos dicho, con mayor seriedad aún. Y se insiste, incluso para el primer mundo, en buscar otra salida al problema del ateísmo por la vía del enfrentamiento con la idolatria. Por decirlo en palabras conocidas, se insiste en enfrentar tcológicamente al no-hombre antes que al no-creyente al plantearse la cuestión de Dios.

Esto, como es sabido, es lo que ha intentado hacer desde sus inicios la teologia de la liberación: enfrentarse con la idolatría. No ha hecho sólo eso en el tratamiento de Dios, pues desde el principio ha insistido en lo concreto del 
Dios de Jesús, en el misterio de Dios, y, correlativamente en la oración, la gratitud, la espiritualidad, etc. Pero en lo que el tratamiento de Dios tiene de problema, indudablemente la teología de la liberación se ha dejado orientar más por la idolatria que por el ateísmo.

Lo que queremos analizar a continuación son las consecuencias para la teología de haberse enfrentado con la idolatría. Digamos claramente desde el principio, para que se nos entienda bien, que tampoco para la teologia de la liberación es suficiente ese enfoque, como lo veremos más tarde; pero creemos que es necesario y fructífero para la teología; y eso es lo que queremos analizar a continuación.

\subsection{Una teología actual y bíblica}

Al enfrentarse con la idolatria, la teologia de la liberación se ha hecho actual y bíblica. A lo primero ya se ha aludido antes al hablar de la idolatría como el signo de los tiempos; no nos vamos a detener más en ello. Lo segundo es lo que queremos analizar ahora, bajo el supuesto de que al hacerse biblica la teología se hace más verdadera y más radical. Este hacerse biblica la teología de la liberación no ha ocurrido fundamentalmente por fidelidad formal a la Escritura o por los descubrimientos exegéticos en otras latitudes y los más modesios en la propia América Latina. Esto ha ayudado, pero no es lo decisivo. Lo decisivo está en que desde la idolatría se ha adquirido una visión de Dios y del mundo más acorde a la de la Escritura.

En esa visión se ha redescubierto que también en la Escritura, como en el mundo de hoy, Dios es una cuestión. En la Escritura existe un planteamiento de la cuestión de Dios, una concreta visión de Dios que se esclarece también dialécticamente desde lo que hay de cuestión en Dios y una visión de lo que es la fe desde esos planteamientos. Con ello queremos decir que sería un error pensar que la realidad de Dios ha existido pacificamente hasta que fue cuestionada por la Ilustración; queremos afirmar más bien que esa realidad ha sido cuestión también en la Escritura y a lo largo de toda la historia de la Iglesia, aunque no se haya usado ese lenguaje. Por decirlo gráficamente, Dios no se hace cuestión sólo con Marx, Freud o Nietzsche; también lo es en Amós, Jeremías, Isaías, Juan y Jesús. La cuestión se presentará de otra manera, pero no quiere esto decir que no la haya ni que sea menos radical que la de aquéllos. Y desde esta cuestión de Dios, expresada bíblicamente, va apareciendo también la realidad de Dios. Veámoslo brevemente en aquellos puntos centrales que iluminan a la teología de la liberación.

La idolatría. Aunque en la Escritura aparecen indicios de ateísmo, más práctico que teórico, la cuestión de Dios no es debatida desde él, sino desde la existencia de dioses falsos. La fides qua tiene que tomar postura ante ellos; $y$ en ese necesario tomar postura se da la posibilidad de la fe y de la nofe. Para creer hay que superar la tentación del culto a los idolos, y dejar de creer no es simplemente prescindir de Dios, sino volverse a los ídolos, la apostasía. Desde este punto de vista, el pecado original hislórico de Israel estaria en la adoración del becerro de oro en el desierto, en un acto idolátrico. 
Desde esıa perspectiva es esclarecedora la formulación del primer mandamiento: "Yo soy el Señor, iu Dios, el que te sacó de la tierra de Egipto, de la casa de servidumbre. No tendrás otros dioses ante mí" (Dt. 5,6-7). La formulación es dialéctica y eso es lo que queremos recalcar ahora: no se puede aceplar a Dios y a los otros dioses. Una razón está en que Dios es quien los ha salvado, mientras que los otros dioses son vacios, inanes. En ellos no se puede depositar la confianza porque no otorgan lo que prometen; hacen vacios lambién a sus adoradores: "yendo en pos de la vanidad se hicieron vanos" (Jer. 2,5).

Esta inanidad de los dioses suele recalcarse, con razón, en la teologia progresista, pero la teologia de la liberación se fija en otro punto no menos, sino más importante. Aunque inanes en sí mismos, el hombre se forja sus dioses y entonces éstos dejan de ser inanes y se hacen muy activos. El hombre diviniza, hace dioses, los instrumentos de poder y entonces los "otros dioses" no son sólo distintos al Dios verdadero, sino contrarios a él. Cuando se diviniza lo creado acaecen varias cosas por necesidad. Dicho sistemáticamente, acaece el error con respecto a Dios, acaece más importantemente la ingratitud con respecto al Dios que ha salvado, pero acaecen sobre todo las victimas. Así lo recalcan los profecas. La divinización de la riqueza produce víctimas, "huérfanos, viudas, emigrantes, pobres, débiles, miserables e incluso los mismos padres aparecian como victimas del deseo de enriquecerse. ${ }^{499}$ Esas victimas son las que muestran que ha habido divinización de lo que no es Dios, las que explican la maldad - no sólo inanidad- de la idolatría y las que proporcionan lógica interna a la formulación del primer mandamiento en forma dialéclica. Esta lógica no proviene, por supuesto, de una arbitraria afirmación de Dios, ni siquiera del exclusivismo monoteista o monolátrico. Proviene de la misma realidad de Dios y de los dioses. Si el Dios de Israel se ha mosirado como liberación y vida y si los otros dioses son dioses de muerte, que producen víctimas, entonces el sincrelismo es imposible; no se puede adorar a Dios " $y$ " a otros dioses, porque están en estricta contradicción. La fe es entonces aceptar al verdadero Dios haciendo contra los ídolos. El verdadero pecado conıra el primer mandamienıo, no sólo contra el segundo, es la idolatria.

La totalidad de la fe en Dios es más que la superación de la idolatria, pero ésta constituye un elemento esencial a esa fe. Lo que hay de debate en lorno a Dios no es su existencia o no existencia, sino la elección entre Dios e idolos. Esto quiere decir que el problema de Dios se plantea primariamente en términos de vida o muerte, de dar vida o dar muerte. Aqui está la alıernativa ınás radical que debe enfrentar la fc, no suficiente, pero necesaria; elegir entre el Dios de vida y los otros dioses, quienes por esencia son "rivales" de Dios. En lenguaje sistemático, elegir entre el Dios cuya gloria es el hombre que vive -el pobre que vive, como parafraseó Mons. Romero- y el Dios cuya vana gloria es el hombre que muere. Vida y muerte, dar vida y dar muerte son las realidades en torno a las cuales se debate primariamente la cuestión de Dios en la Escritura; no son sólo realidades a tener en cuenta después de que ya se ha constituido la reo-logía, sino en el proceso de constituirse ésta.

Existe, pues, la cuestión de Dios en la Escritura y se mantiene como una constante a través de ella, a veces con especial fuerza como en los profetas y en 
Jesús. Y la cuestión no es de hecho, - ni de derecho-, el aleísmo, sino la idolatría: el culto a los dioses quienes producen víctimas. ${ }^{50}$ La leologia de Juan lo ha dicho con fuerza inigualable. Los judios presumen conocer a Dios y Jesús ironiza con ellos porque dicen "El es nuestro Dios;" pero Jesús sentencia, "ustedes no conocen a Dios" (cfr. Jn. 8,545). Y ese desconocimiento no es puro ateísmo, es afiliarse a otros dioses al "diablo" a quien se le llama "asesino" (cfr. Jn. 8,44), al César, quien condena a muerte. El culto al verdadero Dios está descrito en lérminos del amor al hermano, pero su conırario está descrito en términos de dar muerte: "todo el que aborrece a su hermano es un asesino y ningún asesino conserva adentro la vida clerna" (1Jn. 3,15). Asi se plantea, pues, la cuestión de Dios. Como mínimo, pero necesaria y radicalmente, la teo-logía debe ser conscientemente antiidolátrica. Ese "mínimo" es el que aparece en la Escritura, y si se lo ignora, la cuestión de Dios no tiene sentido.

El Dios de las víctimas. La realidad positiva de Dios se desprende, obviamente, de su propia revelación. Ningún previo planteamiento humano de la cuestión de Dios determina cómo es Dios. Pero, una vez. que se ha revelado libremente, la realidad de la idolatria esclarece importantes dimensiones de la realidad del Dios que se revela. El que Dios se haya revelado en y a un mundo de víctimas, no sólo de seres humanos, esclarece - a posteriori- su propia revelación. Veámoslo de manera obligadamente breve.

En la Escritura, Dios se revela como constitutivamente parcial aunque después se pueda y debe universalizar su revelación a todo ser humano. Pero esta parcialidad tiene su propia lógica: Dios se revela parcial porque se revela como liberador de los oprimidos; en nuesıro lenguaje, de las victimas de la historia, de las victimas de los ídolos. Asi aparece en la revelación fundante para Israel: Israel es lo pequeño y lo oprimido. Por ello -en cuanlo los hombres puedan buscar lógica a la libre revelación de Dios- se les revela a cllos, no al opresor, y los defiende. Esta constilutiva parcialidad de Dios - frecuentemente ignorada en la teologia progresista - hacia las victimas recorre toda la Escritura en Trases sencillas, pero fundamentales: "Padre de huérfanos y viudas es Dios" (Sal. 68.5), "En tí el huérfano encuentra compasión" (Os. 14,3) -afirmación que ha sido reconocida como la confessio veri Dei en el Antiguo Testamento." En los profetas, Dios llama "mi" pueblo no a todo Israel, sino a los oprimidos de lsrael. $52 \mathrm{La}$ alianza de Dios con Israel depende de que tenga hacia los oprimidos la misma actilud que tiene Dios: la misericordia (hesed) la actitud de haber justicia (sedaga), la implantación del derecho (mispat). "Un pueblo en el que son conculcados el derecho y la justicia no tiene garantias de supervivencia." 53 Jahvé es el defensor de Israel, el Go'el "porque defiende al pobre." 54 En el Nuevo Testamento J csús anuncia el advenimiento del reino de Dios el cual, en directo, es únicamente para los pobres. 55 Esta parcialidad de Dios no es arbilraria, es más bien "comprensible" si se acepta que la revelación de Dios acaece realmente en una historia donde hay otros dioses que producen victimas. La parcialidad de Dios significa entonces que Dios se revela como Dios haciendo contra los otros dioses y defendiendo a sus victimas. 
También desde las víctimas de la idolatría cobra coherencia lógica el que Dios se manifieste como un Dios del reino, como un Dios que responde a la esperanza de las víctimas, de Israel y de coda la humanidad que dice simplemente que los ídolos no tienen la última palabra sobre la historia, que ésta puede ser configurada de manera que la sociedad humana no sea ya sólo amenaza y destrucción para los pequeños, sino posibilidad y salvación. De ahi que el anuncio del reino sea buena noticia para los pobres y liberación para los oprimidos; y, también, que sean ésıos quienes la entiendan y acojan, pues ellos son los que han estado esperando la aparición del "rey justo," quien por serlo es parcial, quien llega "para ayudar a quienes, por ser débiles, no pueden defenderse." 56

También desde las víctimas cobra coherencia lógica que la relación con Dios sea - aunque no sólo- la de hacer justicia a los oprimidos. No es ése un arbitrario mandamiento de Dios; es la forma de corresponder a su realidad y por ello de relacionarse con él. "Tu padre... practicó la justicia y el derecho hiz.o justicia a pobres e indigentes, y eso si es conocerme"' (Jer. 22,16). El amor a Dios se realiza en el amor al hermano ( $1 \mathrm{Jn} .4,21)$, pero ese hermano es ante todo la víctima (cfr. la parábola del samaritano como respuesta al primer mandamiento).

Citas como éstas pueden multiplicarse, pero digamos con claridad la tesis que queremos afirmar. La revelación de Dios en la Escritura tiene sentido si se tiene ante los ojos a las víctimas de este mundo. Indudablemente en la revelación se hacen afirmaciones universales sobre Dios y sobre el hombre. Pero si esa universalización no se hace desde la parcialidad de Dios hacia los oprimidos -desde la parcialidad originaria en la elección de Israel como pueblo oprimido hasta la parcialidad escatológica de Mateo 25- su universalidad es abstracta, a veces incorrecta y en principio peligrosa, pues se margina lo central en la Escritura: Dios se revela en contra de los ídolos y en favor de sus victimas. Desde las victimas, toda la Escritura comienza a hablar y habla con fuerza sobre Dios y sobre el hombre; pero si se ignoran las víctimas, la Escritura tiende a convertirse en doctrina sobre Dios y sobre el hombre, en competencia con muchas otras, pero perdiendo su originalidad. ${ }^{57}$

Este contexto de las viclimas es el que ha intentado recuperar la teologia de la liberación: el contexto del no-hombre antes que el contexto del nocreyente. Con ello cree también que se le han abierto los ojos para la comprensión positiva de Dios, como Dios de vida, de los oprimidos, de la liberación, del reino; en una palabra, el Dios de las víctimas.

La lucha de los dioses. La idolatria afirma que hay dioses, pero afirma, además, que estos dioses están en lucha excluyente, - no se puede servir a dos señores-, y duélica -uno hace contra el otro. Según eso, la Escritura y la teología de la liberación toman muy en serio el conflicto como estruclura de la misma realidad, como tema teológico fundamental, y recuperan temas tan centrales como la persecución, la cruz y el martirio, con frecuencia olvidados en la teologia progresista.

Si Dios y los ídolos están en contradicción, también lo estarán sus mediaciones y sus mediadores, como lo muesıra paradigmáticamente la Escritura en la cruz. de Jesús. Esıa puede ser estudiada en su dimensión soleriológica, en 
su dimensión revelaloria de Dios y, también en su dimensión escandalosa para la misma fe. Pero hay que verla también desde la idolatría, y sólo desde ella se esclarecen aspectos importantes tanto de la cruz. de Jesús como de la misma idolatria.

A Jesús lo matan históricamente al originarse necesariamente un conflicto enıre él como mediador del verdadero Dios y los jefes romanos y judios como mediadores de los idolos. Este conflicto se origina por que los mediadores defienden mediaciones de Dios diferentes y contrarias: el reino de Dios y la pax romana o la teocracia alrededor del templo. $Y$ detrás de esas mediaciones están diversos dioses. A Jesús lo matan otros dioses y sus mediadores. La disyuntiva de los dioses es clara: "lodo el que pretende ser rey se declara contra el César" (Jn. 19,12), y su lucha también: "Fuera, Tuera. ¡Crucifícalo!' (Jn. 19,15).

Este análisis de la muerte de Jesús no es sólo histórico, sino teologal; es por ello también escandaloso, pues indefectiblemente lleva a la pregunta por el poder de Dios y por el abandono de Jesús a la muerte. Pero antes de intentar dar una respuesta a estas preguntas, hay que ahondar en lo que de inmedialo dice la cruz. de Jesús. Jesús muere como víctima de los ídolos porque se enfrentó con ellos. Jesús muere porque hay idolos y dan muerte. Con ello vuelve a aparecer, y de la forma más radical, la realidad de la idolatria: llega a dar muerte al Hijo. Pero aparece también-la forma original de relacionarse Dios con el mundo de los ídolos.

Dios se revela defendiendo a las víclimas y estando realmente en el mundo que origina victimas. La encarnación cobra aqui una dimensión bien precisa. Encarnación no es sólo asumir forma humana, no es sólo acercamiento al mundo, sino que es introducirse en el mundo de pecado, en un mundo intrínsecamente conflictivo en el que los dioses hacen contra Dios, es mantenerse en ese mundo a través de y a pesar de la persecución, es cargar con el pecado del mundo y estar dispuesto a dejarse abatir por él.

Desde la lucha de los dioses poca duda cabe de que la teo-logia debe ser polémica; y debe ser encarnada de acuerdo a cómo se introduce Jesús en esa lucha.

El modelo del diálogo como forma de relación del creyente - y de la teologia - con el mundo es importante si con ello se quiere superar el triunfalismo y la cerrazón eclesial; pero no es suficiente ni es el modelo primario. El modelo primario es la encarnación en el mundo constituido por graves conflicIos, lo cual producirá persecución y martirio. Una encarnación así no es algo optativo o anecdótico; le es esencial a la fe y necesaria a la teologia. Indudablemente habrá que entender persecución y martirio de forma analógica, según épocas y lugares; pero si desaparece de la realidad, si la teología no hace de ello algo central, es que no ha habido verdadera encarnación, ni desenmascaramiento profético de los idolos. De esta forma se ofrece, además, un criterio de verificación, sencillo, pero eficaz, de si la cuestión de Dios está planteada sólo culturalmente o si se plantea biblicamente. Si la realidad cristiana -y la teología correspondiente- no genera ningún tipo de persecución y martirio, 
por muy analógicamente que haya que comprenderlos, si los poderes de este mundo no reaccionan conira ellas con fuerza, se puede dudar seriamente de que haya tocado en scrio la cuestión de Dios. ${ }^{58}$

La ilustración de la imagen de Dios. Digamos, por úllimo, una palabra sobre la ilustración que la Escritura hace sobre la imagen de Dios, con lo cual se quiere recalcar ante todo que la Escrilura lambién exige una ilustración, pero que no es sin más la del mundo occidental. Como ya se ha dicho, una teologia que intenta responder a la llustración europea enfatiza, por un lado, la trascendencia de Dios y desmitifica determinadas imágenes de Dios. Para ello se apoya también en la Escritura, y recalca así la prohibición de hacer imágenes de Dios para preservar su transcendencia, enfatiza la futuridad e incluso la cruz como modos de ser de Dios, desmitifica también la creación, desenmascara una religión basada en la recompensa y no en la gracia, etc. Se puede decir, en resumen, que la teología progresista enfatiza la necesidad de ilustración de la imagen de Dios, concibe esa ilustración susiancialmente como desmilificación y encuentra apoyo para ello también en la misma Escritura.

Pero creemos que en la Escritura cl proceso de ilustración Ioma otro rumbo sin negar los anteriores. El segundo mandamiento prohíbe hacer imágencs de Dios (Ex. 20,4-6; Dt . 5, 8-10), pero la razón fundamental de esa prohibición no hay que buscarla direciamente en preservar a la le de adecuar a Dios con algo material o en recalcar que nada creado puede abarcar a Dios. Eso es verdad, pero no es la razón fundamental para la prohibición. Según $P$. Miranda, 59 la razón está en otra cosa: la imagen no puede hablar, no puede interpelar, no puede exigir una práctica de acuerdo a la realidad de Dios. Eso lo origina la palabra. "Entonces te habló el Señor en medio del ruego; iú escuchabas los sonidos de palabras, pero no veías forma alguna: sólo había voz." (D1. 4,12).

Ilustración no significa aqui directamente desmitificación de una determinada imagen de Dios, sino exigencia de aperlura a la voz. de Dios si en verdad se quiere llegar a conocerlo. "El Dios de la Biblia no es capiable como neuiro; deja de ser Dios en el momento en que la intimación cesa. Y el hombre dispone de muchos recursos para hacer que la interpelación cese." 60 llustración significa, por lo lanto, descubrir cualquier mecanismo que defienda al hombre contra la intimación de Dios. Cuando eso ocurre, deja de ser relevante si el hombre tiene imagen concreta de Dios o qué tipo de imagen tenga; lo importante es si a través de cualquier imagen más o menos adecuada de Dios se ha permitido o no la interpelación de Dios. "Si (el hombre) de cualquier manera neutraliza su ser-interpelado, ya no es Dios a quien adora." 61 Y ese lipo de ilustración tiene una dimensión verdaderamente universal en la Escritura; no se exige sólo de los creyentes en Jahvé, sino de todo hombre. "Israel estaba obligado a atenerse a la voz, al sonido de las palabras, y a renunciar a toda figura... Para Pablo los gentiles están bajo la misma obligación que Israel."62

Este tipo de ilustración, la supremacia de la voz sobre la imagen, exige en positivo la correspondencia del creyente con la realidad de Dios. Y ello, paradójicamente, lleva a que el Dios-misterio, superior a cualquier imagen, en un punto haya dejado de ser misterio. Por inefable que sea la Iranscendencia de 
Dios, por insalvable que sea la distancia cualitativa entre Dios y hombre, en la interpelación Dios se acerca con absoluta luminosidad y absoluta intimidad. "La voluntad de Dios no es misterio por lo menos en cuanto atañe al hermano y se trata del amor."63 Y tampoco es misterio por lo que toca a su contrario. La Escritura ilustra sobre la imposibilidad de acceder a Dios, sea cual fuere la imagen o conceptualización que se hiciere de Dios, incluso la ortodoxa, si hay una práctica contraria a Dios. "Aunque menudeen la plegaria, yo no les oigo. Sus manos están manchadas de sangre: lávense, quiten sus fechorias de mi vista, desistan de hacer el mal, aprendan a hacer el bien, busquen lo justo, den sus derechos al oprimido, hagan justicia al huérfano, aboguen por la viuda" (Is. $1,15-17)$. "Esta es la religión auténtica: ayudar a los huérfanos y viudas" (Sant. 1,27). Y la teologia de Juan, de nuevo, lo dice con meridiana claridad y con intención claramente "ilustrante" sobre la verdad de Dios. "Si alguien dice 'amo a Dios' y aborrece a su hermano, es un mentiroso; pues quien no ama a su hermano, a quien ve, no puede amar a Dios a quien no ve" $(1 \mathrm{Jn} .4,20)$. "Quien dice 'yo lo conozco,' pero no cumple sus mandamientos, es un embustero; ése no lleva dentro de la verdad" (1Jn. 2.4). Dicho en positivo "quien habla de estar con Dios tiene que proceder como procedió Jesús" (subrayados nuestros). (IJn. 2,6).

No se puede decir con más claridad en qué consiste la fundamental ilustración del conocimiento de Dios: a la verdad acerca de Dios se le opone ante todo la propia mentira, y la superación de ésta es ante todo una praxis, un proccder como Jesús. En la Escritura ilustrar significa en primer lugar corregir la praxis antes que corregir la imagen o idea.

Por eso esła ilustración va más en la linea de la desidolatrización que de la desmitificación de la idea de Dios; dicho positivamente, va más en la línea de corresponder a Dios en su realidad con nuestra realidad que en la de explicitar adecuadamente su realidad.

Pero hay olro tipo de ilustración que opera la Escritura, la más específica y la más escandalosa: Dios se ha hecho presente en el siervo sufriente. Este siervo es presentado como quien intenta instaurar el derecho y la justicia, como quien entra en confliclo con tos idolos de este mundo y termina siendo su vícima. Y de esc siervo despreciado, tenido por maldito, se dice que es "luz."

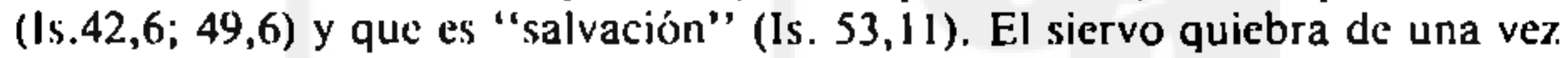
por codas nuestras imágenes de Dios, pero - además - afirma dónde está Dios y dónde está como Dios, como verdad (luz.) y salvación.

La cruz de Jesús cjemplifica a cabalidad la figura del siervo y la teologia de la liberación la prolonga en los pueblos crucificados.64 Afirmar que in el siervo está Dios es la más escandalosa ilustración de la imagen de Dios; pero no sólo por ser la iconoclastia de ıodas nuestras imágenes - aspecio recalcado también por la teologia progresista- sino por ser el lugar de Dios. Esta ilustración no tiene nada de razonable, pero sin ella no hay conocimiento verdadero de Dios. La teologia de la liberación la hace central en su mélodo ${ }^{65}$ y contenidos: los oprimidos, los pueblos crucificados, son hoy el siervo de Jahvé, son el lugar de la presencia de Dios, de forma crucificada ciertamente, pero alli está Dios, alli hay luz y salvación. Puede ser que no se encuentre a Dios en el sicrvo 
sufriente; pero si no se lo encuentra alli, no se lo encontrará en ningún otro lugar como el Dios cristiano. Y ninguna ilustración, de tipo occidental, lleva mecánicamente a encontrar a Dios en el siervo. Para ello se necesila otro tipo de ilustración, la ilustración de la Biblia. Recordemos a Pablo: "Cuando Dios mostró su saber, el mundo no reconoció a Dios a través del saber" (ICor. $1,21)$, porque Dios lo mostró en la cruz de Jesús.

Por todo lo dicho, sería un error pensar que la ilustración de la imagen o de la idea de Dios es sólo un fenómeno que comienza con la edad moderna o con los griegos. También en la Escritura - y a lo largo de toda ella - hay un constante proceso de ilustración. Pero su camino y su finalidad son otros: hay que dejar a Dios ser Dios en su interpelación y hay que buscar su presencia en lo pequeño y crucificado de este mundo. Sino se da esta ilustración, todas las demás ilustraciones son para la Escritura, secundarias. periféricas y distrayentes de la verdadera cuestión de Dios.

Con las reflexiones de este aparato se ha pretendido mostrar que una teologia que se constituye contra la idolatría se hace más actual y más bíblica. Ello no es suficiente para expresar toda la realidad de Dios, pero es muy fructífero para recuperar aspectos sumamente importantes de la revelación de Dios que con mayor dificuliad son recuperados en otras teologias: el Dios del reino y el reino de Dios, el conflicto, los pobres y su esperanza, la justicia, la cruz., etc. De esta forma, la misma teologia se hace más biblica porque recupera el talante anti-idolátrico y profético, se hace más encarnada y práxica. Se hace sobre todo más "evangélica" porque presenta a Dios como buena noticia a las victimas de la idolatría; y se hace más "popular" porque se piensa a sí misma desde y para los pueblos crucificados. Pero todo esto es posible cuando se ve a Dios desde las víctimas y no desde sus opresores.

\subsection{La teologia de la liberación y la pregunta por Dios}

La teologia de la liberación se constituye contra la idolatría y con consecuencias positivas. Pero precisamente por ser una teología antiidolátrica, es decir, porque toma absolutamente en serio la existencia, el poder y la crueldad de los ídolos, se ve confrontada desde deniro con la pregunta por Dios. ¿Qué es de ese Dios de la vida, tan permanentemente perdedor en la lucha de los dioses? "¿Cómo anunciar el Dios de la vida a personas que sufren una muerte prematura e injusla? ¿Cómo reconocer el don gratuilo de su amor y de su justicia desde el sufrimiento inocente? ¿Con qué lenguaje decir a los que no son considerados personas que son hijas e hijos de Dios?" 66 pregunta G. Gutiérrez. "Hace tiempo que siento la desaparición de pueblos enteros como un absurdo misterio de la iniquidad histórica que convierte mi fe en abatimiento. Señor, ¿por qué los has abandonado,?"67 pregunta Pedro Casaldáliga. Antiguas y perennes preguntas de Job y de Jesús, de Dostoievski y de Camus. En el primer mundo sigue siendo la gran pregunta también: cómo hablar de Dios después de Auschwilz. ${ }^{68}$

No hay ingenuidad en la teologia de la liberación con respecto a Dios porque no hay ninguna ingenuidad respecto a la realidad histórica. En el tercer 
mundo la misma realidad es escándalo; no produce la admiración aristotélica ni la sorpresa heideggeriana de por qué hay ser y no nada, sino que produce indignación y la queja de por qué la muerte priva sobre la vida (I. Ellacuria). El sufrimiento inocente, masivo y duradero, convierte a la misma realidad en problema y escándalo. Con o sin Dios esa realidad es el escándalo primario. Si existe Dios, la realidad se hace, además, escándalo para el creyente que no sabe cómo compaginar al Dios bueno y la realidad mala; pero -aunque no existiera- no desaparece el escándalo de la rcalidad, y sólo sería consuelo "liberal" condenar a Dios para que no hubiese escándalo a nivel racional. El escándalo es, por lo tanto, hondo, muy hondo. Plantea la pregunta por la teodicea, pero también por la antropo-dicea y la onto-dicea.

En el contexto de ese radical escándalo, la teologia de la liberación se pregunta por Dios y no escamotea el problema. La pregunta es poderosa tanto desde la misma realidad como desde la imagen de Dios que elabora esa teología, como Dios de la vida, como Dios de los pobres. "El silencio de Dios es más insoportable para quien cree que el Dios de nuestra fe es un Dios vivo y no como aquellos, de guienes el salmista se burla, que "tienen boca pero no hablan' (Sal. 111,5)."

La teología de la liberación intenta dar una respuesta a esta pregunta, pero -aunque conoce y valora este modo de proceder- no lo hace de forma meramente conceptual y argumentativa. Lo más especílico suyo es argumentar desde la fe realizada en presencia de un posible y comprensible ateismo ante el silencio y la impotencia de Dios. Metodológicamente, toma en serio, también aquí, los signos de los tiempos, la realidad tal cual es, y en ellos observa no sólo la injusticia y la idolatría, sino también el amor y la esperanza. 70 Existe fe y gran fe entre las víctimas y entre quienes las acompañan, existe el amor y el mayor amor de quienes dan la vida por sus hermanos, miles de mártires; existe esperanza y gran esperanza en la vida, en la posibilidad de fraternidad, en el advenimiento del reino de Dios. Este es el hecho y, en un sentido, no se puede ir más allá de él. En medio del escándalo de la historia surge un sentido que hace vivir en esa historia, que hace trabajar y luchar para Iransformarla y que da esperanza. Y ese sentido es otorgado por Dios.

Dos cosas quisiéramos tratar de explicitar de ese hecho. La primera es que esa fe no puede comprenderse simplemente como la aceptación ingenua de una fe transmitida. Indudablemente muchos la han recibido y la aceptan sin cuestionarla; pero esa recepción significa un re-hacer la fe, estar en la situación primigenia donde se puede o no se puede creer, y llegar a creer. En el tercer mundo la fe llega a ser como en los grandes momentos de la Escritura. La fe, como en Abraham, significa lanzarse a lo desconocido, abandonar lo antiguo y transitar caminos nuevos sin conocerlos de antemano, teniendo como toda garantía una palabra (de Dios). Como en Moisés, la le significa decidirse a una tarea imposible, la liberación de un pueblo, sin más armas que ser enviado (por Dios). Como en Jeremias, la fe significa pasar la prueba del escarnio y la persecución, la prueba del silencio de la palabra que envió al profeta, donde no queda ya más que un fuego ardiente en el corazón (puesto por Dios), con el cual se lucha para apagarlo, pero ante el cual uno se rinde. Como en Jesús, la 
fe significa la gran misericordia hacia los hombres y la gran fidelidad, aunque esto cueste lágrimas, no saber y la cruz, manteniendo hasta al final la fidelidad (a Dios). Con esto queremos decir que en el tercer mundo hay le y se está rehaciendo la fe desde su más profunda originalidad. El milagro de la fe vuelve a ocurrir, aunque teóricamente pudiera esperarse que lo liene todo en su contra. Sigue habiendo una nube de testigos de la fe, como en Hebreos 11, testigos que se asemejan a Jesús, quien vive originariamente y en plenitud la le. Siguen a Jesús, hacen milagros y exorcismos, denuncian y desenmascaran la opresión, entran en conflicto y son perseguidos, aman a los pobres hasta el final y son crucificados. Y en todo ello, como Jesús, invocan a Dios como Padre.

La constatación de este hecho es importante, no sólo por lo que tiene de llamativo y heroico, sino para la argumentación teológica. En el momento de mayor agudeza de la crisis existe la le; en la realidad concreta de los seres humanos la fe es una posibilidad porque es una realidad. Si el ateísmo es una posibilidad razonable, la fe también lo es. Si en la historia de la humanidad se puede llegar a un momento grandioso donde los seres humanos dan muerte a Dios, también en esa historia - y en los escandalosos momentos actuales- se llega a momentos grandiosos de creer en Dios.

Este es el hecho en sí mismo y no se puede ir más allá de él. La fe es una posibilidad para los seres humanos y muchos - sin ingenuidad, sin rulina - la hacen realidad. Esto es verdad en cualquier lugar donde ocurra la fe, pero podemos preguntarnos, en un análisis lógico, por la posibilidad de la fe en la situación del tercer mundo donde parece triunfar la idolatria, donde la fe tiene que tener en cuenta, por lo tanto, un aspecto de terrible oscuridad y un aspecto de claridad en cuanto es fe realizada.

Nos parece que dos cosas se combinan en la fe real que pueden ser esclarecidas por la solemne sentencia del profela Miqueas: "Se te ha declarado, oh hombre, lo que es bueno, lo que Jahvé reclama de tí: que practiques el derecho y ames la lealtad, y que camines humildemente con tu Dios" (Mi. 6,8). Hay algo absolutamente claro en lo que es bueno para el hombre: la práctica de la justicia, la lucha contra la idolatría. Sobre esto no debe quedar duda, sea cual fuere la oscuridad sobre otras cosas. Si la práctica de la justicia se oscurece por razones prácticas o por razones leóricas - para qué la justicia si en último lérmino nunca triunfa- se ha viciado ya el proceso de la fe. $Y$ hay algo que es por su naturaleza oscuro: caminar con humildad, sin saber exactamente hacia dónde se va, ni el cuándo de la llegada. Se nos habla aquí de una antropología posiliva: hacer la justicia y de una teologia negativa: caminar humildemente.

El aspecto de oscuridad y de ambigúedad lo inmortalizó Machado con sus versos: "Caminante no hay camino, se hace camino al andar;" versos que se citan aqui porque desde América Latina se los ha reinterpretado en la línea de. Miqueas. Dice Pedro Casaldáliga. ${ }^{71}$

Camino que uno es

que uno hace al andar.

Para que olros caminantes

puedan el camino hallar.
Para que los atascados

se puedan reanimar.

Para que los ya perdidos

nos puedan reencontrar. 
La reinterpretación se basa en el descentramiento del "propio" caminar: " Haz del canto de tu Pueblo el ritmo de tu marchar."72 Ese descentramiento es lo primero exigido por Miqueas: hacer la justicia es un caminar con y para otros. Y ese caminar descentrado es lo que puede hacer que el humilde caminar sea comprendido como un caminar con Dios.

Dos elementos hay, pues, para el hombre en presencia de la idolatria: luchar contra ella y comprender ese hacer justicia como caminar con Dios. En pura lógica lo uno no lleva a lo otro mecánicamente; pero pueden coincidir los dos y de hecho coinciden en la fe realizada. Dicho sistemáticamente con palabras de G. Gutiérrez a Dios hay que contemplarlo y hay que practicarlo. ${ }^{73}$ La relación con Dios es de alteridad y de afinidad. La fe exige como necesaria la afinidad -el ser "según Dios" en la práctica de la justicia- y ello puede, y muchas veces se hace realidad, coincidir con dejar a Dios ser Dios, contemplar a Dios. Creemos que eso ocurre en la fe realizada en medio de la idolatria: la lucha contra ella, que es el amor, hace caminar en afinidad con Dios y hace comprender que es con Dios con quien se camina.

Un último elemento hay que analizar en la experiencia de la fe realizada; elemento dificil de poner en palabra, pero decisivo para la fe, la experiencia de gratuidad. Es experiencia repetida que muchos seres humanos no soblo caminan haciendo la justicia, sino que novedosamente "se encuentran" haciendo la justicia. "Se encuentran" con nuevos ojos para ver las cosas de manera muy distinta y se encuentran con manos nuevas para hacer cosas muy distintas. "Se encuentran" en la práctica del amor, con su novedad, con su dificultad, sus exigencias y riesgos, con su generosidad y su entrega hasta el final. La realidad no sólo ha mostrado toda su crueldad, sino que ha transparentado también sus mejores posibilidades, donde abunda el pecado sobreabunda la gracia. Puesto en palabras de hombres, hay que decir que "algo se nos ha dado," "ha aparecido la benignidad sobre la tierra." Los campesinos lo dicen de forma sencilla: "antes no éramos pueblo, ahora lo somos," más solisticada, el Señor ha vuelto a aparecerse en América Latina y ha desencadenado misión y gozo. ${ }^{75}$

Esa experiencia es también verdad, existen hoy los libres para amar. ${ }^{76} \mathrm{Pe}$ ro esos que se saben hoy libres, o más libres que antes, han sido ellos mismos liberados, su amor tiene su origen en otro amor más grande que libera para el amor. Las mediaciones históricas de esa experiencia son múltiples: la generosidad de los pobres, la entrega de los mártires, el perdón que nos otorgan, etc. 7 Pero la conclusión es lo importante, en esta realidad trágica no sólo hay pecado, hay amor y ese amor se contagia, libera para el amor a los otros. Desde estas mediaciones históricas se puede releer la Escritura "con sentido:" Dios es amor, el ha amado primero. Eso exige que haya amor en este mundo, pero, además, lo posibilita. El caminar en la historia haciendo la justicia no es sólo un caminar kantiano o prometeico; es un ser llevados por un amor más grande -misterioso e incomprensible-, pero amor al fin y al cabo que posibilita nuestro amor. Ese amor que está en el fondo de la realidad no es todopoderoso, Juan y Pablo recalcan que se ha expresado precisamente en la impotencia del Hijo crucificado; pero es real. De ese amor primigenio se echa mano una y 
otra vez para seguir caminando en la justicia, y ese amor mueve a seguir caminando. Ese amor, sin comprenderlo, sin que pueda responder a las preguntas de la teodicea en directo, es lo que "explica," no necesariamente la historia, pero si el que se siga haciendo historia según el amor. Eso es lo que aparece como el don. Se camina en la historia con Dios, pero llevados por el amor de Dios.

Un caminar así produce esperanza; el caminar tiene sentido. "La queja no excluye la esperanza," 78 ni el sufrimiento excluye el gozo. ${ }^{79}$ Muchas preguntas categoriales permanecen sin respuesta, pero una se impone para la fe, vivir según el amor de Dios es bueno, es bueno para el hombre y es bueno para la historia. A él acuden una y otra vez las víctimas de la historia y en él encuentran su última esperanza.

Esta es, creemos, la fe realizada en medio de la idolatría. La breve fenomenología de esa fe no fuerza a aceptar a Dios, como tampoco la fenomenología que está detrás de la teodicea fuerza a no aceptarlo. Pero si muesira que la fe es una posibilidad, con la cual el hombre libremente tiene que habérselas. ${ }^{80}$ En lo que hemos querido insistir es que esta posibilidad no se analiza sólo desde la constitución transcendental del ser humano, sino desde el hombre en un mundo de idolatria. Esta puede ser la mayor tentación para la fe, pero puede ser también - paradójicamente- su mayor posibilidad. Al menos, asi ocurre en la Escritura y en América Latina.

La teologia de la liberación se interesa, por lo lanto, en el ateísmo, no sólo en la idolatría. Pero no of rece una superación de aquél en directo, sino, como Miqueas, a través de la práctica de la justicia, a través de la lucha contra la idolatría. En esa activa lucha, no sólo en la distante contemplación de las victimas, se decide la fe. Puede ser que alguien niegue o prescinda de Dios en esa lucha; pero puede ser también - y es una realidad-que en esa lucha el ser humano se sepa caminando con Dios, llevado por Dios y dirigiéndose a Dios.

\section{Una palabra final}

Las páginas precedentes, demasiado ldrgas rujizás para decir algo muy sencillo, se resumen en lo siguiente. Ateismo e idolatría son realidades en nuestro mundo de hoy ${ }^{81}$ que hacen de Dios el ausente o el crucificado, y que expresan la crisis del hombre, el sin sentido de la existencia y la activa falta de solidaridad con los otros hombres o, peor aún, el hacerlos víctimas. Unas teologías intentan enfrentarse al ateismo en directo y recuperar así a Dios y al hombre. Otras, aparentemente más modestas, intentan ante todo combatir a los ídolos, exigir y animar al hombre a la práctica de la justicia, de la solidaridad con las victimas, con la esperanza tambièn - fundada en la experienciade que en ello se haga presente Dios y el Dios de Jesucristo.

En principio ambas tareas son buenas y necesarias. Creemos que la segunda es más actual y bíblica y, quizás, la más eficaz. Pero también desde el primer mundo comienzan a verse asi las cosas. Enfrentarse con el ateismo, responder a la secularización y al relo de la Ilustración es bueno, pero se muestra cada vez más insuficiente. En las palabras finales del congreso de teología anles mencionado dijo J. Gómez Caffarena: 
Nuestro mundo occidental da hoy una pobre imagen de sí. Sin quitar valor a lo dicho en la primera parte, añadamos: hemos pasado la crisis de la secularización. Era necesaria y, como hemos visto, ha podido ser purificadora. Pero va resultando sospechoso constatar que nos ha dejado como desconcertados, obsesionados con nuestros problemas intelectuales. Si somos sinceros, quizás debemos confesar que esa especie de difuso nihilismo, de desesperación tranquila que sentimos no es sólo el impacto de la secularización, es también que estamos enervados por la comodidad, por el ansia de tener que fomentan las propagandas de la sociedad de consumo; estamos -y esto es peor - deshumanizados hasta habernos hecho sordos al clamor humano del mundo. Esta es la mayor decadencia de occidente. Pero no tenemos que dar por Tatal lo que nos ocurre. Todo puede curarse, si nos decidimos a vivir con coherencia la llamada de la fraternidad. ${ }^{82}$

De nuevo se nos propone aquí, como en Miqueas y como en Jesús, el descentramiento fundamental de nuestra vida: no ser sordos al clamor humano, decidirse a vivir la llamada de la fraternidad. Ese descentramiento sigue siendo esencial también para hacerse la pregunta por Dios. Sin él, pervive de hecho el egocentrismo o el egoísmo, y Dios no se hace presente. Con él, Dios pucde aparecer como el Otro escondido en los otros, como el Dios de vida escondido en las víctimas. Eso es lo que afirman muchos creyentes en el mundo de hoy: en el dar vida y la propia vida han encontrado la verdadera vida, en ese gran otro que es una humanidad crucificada han encontrado a Dios. Y - añadamos- en el buscar no sólo han encontrado, sino que han sido encontrados por Dios. Dios aparece como don.

Creer en Dios hoy, más que la respuesta a un problema, es la acogida a una invitación. Una invitación a caminar en la historia "según Dios," a defender a las víctimas y a practicar la justicia. En ese caminar no desaparecen los problemas, pero el problema de Dios se va convirtiendo en el misterio por antonomasia: el misterio que es absoluta exigencia y buena noticia utópica, el misterio que crea amor y esperanza. En la historia nos toca cargar con ese misterio, pero podemos sentir también que somos cargados por él. Así la historia del amor y de la justicia es también la historia del caminar con Dios con la esperanza última de dirigirnos a Dios.

\section{NoTAS}

1. "Dios de vida, idolos de muerie," V Congreso de Teologia, Madrid, 4-8 de sepliembre de 1985. Las ponencias y demás intervenciones han sido publicadas en Misión Abierı, noviembre, 1985.

2. Junto a la ingente producción sobre eclesiologia y cristologia, la teologia está explicitando el tema de Dios. Ello responde a la intuición, ya formulada por K. Rahner, de que si la reo-lo gia debe concentrarse crislológicamente, no puede reducirse a ello.

3. La comparación entre ambos tipos de teologia la hemos llevado a cabo en "El conocimiento teológico en la tcología europea y latinoamericana," en Resurrección de la verdadera lglesia, Santander, 1981, pp. 21-53; "Teologia de la liberación y teologia progresista europea," $M i$ sión Abierıa, 1984, 77, pp. 395-410. Hay que repetir, una vez más que primer y tercer inundo no son considerados simplemente como realidades geográficas, sino como realidades históricas y teológicas. Por ello hablamos de teologias del primer y tercer mundo; $y$ por ello hay 
teologias en el primer mundo que se hacen con afinidad a la del tercer mundo y a la inversa. Asi lo prueban las citas de teólogos europeos que aducimos en apoyo a las tesis de la teologia de la liberación.

4. W. Kasper, El Dios de Jesucristo, Salamanca, 1985, p. 17s. En este articulo citaremos con frecuencia este libro. Junto a sus méritos y utilidad, representa en nuestra opinión lo que hemos llamado la teología progresista y, quizás, cl tipo de teologia que sce está imponiendo en el Vaticano, como lo mosiraria el documento del sinodo extraordinario de obispos en Roma, diciembre de 1985.

5. Ibid., p. 18.

6. "La incredulidad como problema teológico," Concilium 1965, 6, p. 66s.

7. Véase nuestro articulo, "Espiritualidad y teologia." Revista Latinoamericana de Teologia 1984, 2, sobre todo pp. 215-223.

8. Mision Abierta, p. 5.

9. Escritos de Teologia IV, Madrid, 1964, p. 153.

10. Mision Abierı, p. 6.

11. W. Kasper, op. cit., p. 22s.

12. Die Sehnsucht nach dem ganz Anderen. Hamburg, 1979, p. 88s.

13. Ibid., pp. 62.76.

14. W. Kasper, op. cir, 27.

15. Ibid. Kasper termina su libro afirmando que "la confesión trinitaria (es la) respuesıa al ateismo moderno" (p. 356).

16. Ibid.

17. Frei Betto, "Dios brota en la experiencia de la vida," en Varios, La lucha de los dioses, San Josć, 1980, p. 193.

18. Aunque no sea usual apelar a las biografias de los teólogos, hay que recordar que por formación y/o nacimiento los teólogos latinoamericanos han conocido en Europa las leologias de la secularización y de la muerte de Dios. Su disıinıo planteamiento del problema de Dios no proviene, pues, de desconocimiento. Más bien habrá que apreciar que conociendo ambos planteamientos se hayan decidido por uno, lo cual no sucle ocurrir en la teologia progresisıa que sólo conoce un planteamiento.

19. Véase el último libro de G. Gutiérrez, Hablar de Dios desde el sufrimiento inocente. Una reflexión sobre el libro de Job. Lima, 1986. Hace años escribimos: "El abandono de Dios en la cruz de Jesús y el abandono de Dios sentido en la historia de la injusticia y de la opresión, el grito de Jesús en la cruz y el grito de las viclimas de la historia no permite una fe ingenua en Dios, sino una fe que vence al mundo," Cristologla desde América Latina, México, 1976, p. 182.

20. "Misión de la Iglesia en medio de la crisis del pais," en J. Sobrino, I. Martin-Baró y R. Cardenal, La voz de los sin voz, la palabra viva de Mons. Romero, San Salvador, 1980, Pp. 125172. Para el análisis de la idolatria, véase pp. 145-149.

21. Varios, La lucha de los dioses; G. Gutiérrez, El Dios de la vida, Lima, 1981; La fuerza his'órica de los pobres. Lima, 1979; I. Ellacuria, Conversión de la Iglesio al reino de Dios, San Salvador, 1985; Victor Anaya, El Dios de los pobres, San José, 1983; J. Luis Segundo, Nuestra idea de Dios, Buenos Aires, 1970. El hombre de hoy ante Jesu's de Nazaret I, Madrid, 1982; J. Sobrino, Resurrección de la verdadera Iglesia, sobre todo pp. 177-266, Oscar Romero, Lima, 1981 sobre todo pp. 15-65.

22. Teologia desde la praxis de la liberocion, Salamanca, 1973, p. 40.

23. La CEPAL acaba de pronosticar que a final de siglo 170 millones de latinoamericanos vivirán en situación de extrema pobreza, que será sumarnente dificil su alimentación básica, y nada se diga de otras necesidades vitales, como salud, vivienda, educación, etc.

24. 1. Ellacuria, "Discenir el 'signo' de los tiempos." Diakonia 1981, 17, p. 58.

25. Véase en este mismo número el articulo de J.I. González Faus, "Pecado estructural, pecado del mundo."

26. A no ser que se adecúc concepiualmente aleismo con la idolaıria, cosa que puede ocurrir, pero que no tiene por que ocurrir. Sobre una precipitada adecuación de ambas cosas en la teologia progresista, véase el comentario que se hace más abajo al libro de Kasper.

27. Nuesira idea de Dios, p. 18.

28. Ibid. 
29. El hombre, Salamanca, 1973, p. 45. La misma intuición aparece en su cristologia: para hacer justicia a Jesús hay que cambiar la perspectiva de preguntar por Jesús a dejarse ser preguntado por él, Cfr. El Dios crucificado, Salamanca, 1975, pp. 116-156.

30. Otras teologias en el primer mundo se han orienıado también hacia la critica teológica de la sociedad. Véase por ejemplo, J.B. Melz, La fe en la historia y en la sociedad, Madrid, 1979; Más allá de la religión burguesa. Salamunca, 1980; J. Moltmann. "Theolo-gische Kritik der politischen Religion," en Varios, Kirche im Prozes der Au/klarung, München, 1970.

31. J.L. Segundo, op. cit., p. S0. La cila prosigue: "Más aún, su enjuiciamiento del sistema social lo lleva necesariamente a la critica de una noción de Dios en quien se proyecta la falsa imagen creada por una ideologia de dominación. En este sentido podemos decir que nunca como hoy ha sido lan dilicil de concebir exislencialmente el Dios cristiano."

32. Ibid., p; 21. La "mutilación" consiste en una existencia donde ya no caben las preguntas por cl sentido y la finalidad de las cosas; piro esa existencia es producto de una determinada sociedad que es la que se acepla sin critica en sus raices más profundas. Por eso se pregunta J.L. Segundo: " $i Y$ si Dios denunciara precisamellte en su mensaje ese "mundo nuevo" como un mundo en que el hombre formula preguntas y busca respuestas desde una existencia mutilada y alienada"? (p. 21).

33. "Alcismo," en Sacramentum Mundi I, Barcelona, 1973, p. 466.

34. Op. cil., p. 69.

35. "Quien luc!ic contra el ateismo como fenómeno social de masas, en primer lugar debe tomarlo en serio y conocerlo, ha de valorar sus causas y argumentos, confesando Iranquila y abierlamente que con frecuencia se ha abusado del teismo y se lo ha convertido en "opio del pueblo;" debe además desarrollar un dílogo auténtico y sincero con los ateos, aceptando toJos sus presupuestos y exigencias y, ell consecuencia, estando incluso dispuesto a colaborar con los alcos en la configuración del mundo común. La "lucha" no puede centrarse solamiente en el campo de la doctrina; más bien se ha de combatir sobre todo mediante el tesimonio vivo de cada cristiano y de la Iglesia entera, mediante una continuada autocrilica, purificación y renovación, medianle el argumento de una vida religiosa que esté libre de superstición y de falsa seguridad. A tsıas armas han de sumarse la práctica de la justicia, de la unidad y del amor verdaderos y, con ello, el teslimonio de que un hombre, creyendo y esperando, puede aceptar la penumbra de la existencia como nacimiento de un nuevo sentido infínilo para ésta, el cual es precisamente el Dios absoluto, que se comunica a si mismo," K. Rahner, op. cil., p. 468.

36. J. 1. González. Faus, "Imágenes de Dios," Misión abierı. p. 34. Una ampliaciòn de ese articulo puede verse en J. 1. González. Faus, Josep Vives, Creer sólo se puede en Dios. En Dios sólo se puede creer, Santander, 1985, pp. 7-69.

37. lbid., p. 35.

38. Un ejemplo de esto puede verse en los diversos significados que se atribuyen al redescubrimiento del Jesús histórico en la crisılogía. Asegurado el hecho masivamenle en la actualidad, unas cristologias recalcan más la importancia de ese Jusús para el sentido de la propia vida y otras para la práctica, cfr. J. Sobrino, Jesiis en América Latina. Santander, 1982, pp. $110-123$.

39. La cita complela donde se expresa esta dificultad es la siguiente: "Un buen amigo me indicaba hace poco tiempo su preocupación por lo que él describia como una creciente "islamización" de la imagen de Dios a manos de algunos de los Ieólogos más recientes. Se referia con ello a la forma en que cierıas corrientes teológicas utilizan a Dios como motor principal de una "guerra santa" en Tavor de los más pobres o desvalidos y contra cualquicr clase de injuslicia, opresión o discriminación. Dios es demasiado sanıo y excelso para que podamos atrevernos a complicarle tan inconsideradamente en nuestros asuntos... Deberiamos seguramente atender a no implicar con exceso la misma imagen del Dios trascendente en nuestros problemas, no sea que acabemos adorándole no como es en si mismo, sino como nos conviene a nosotros... Es preciso rechazar decididamente estos dioses consıruidos a escala excesivamente humana y reafirmar la fe en el único Dios, iranscendente, tudopoderoso, creador del cielo y de la tierra," "El idolo y la voz. Reflexiones sobre Dios y jusıicia," en Varios, La justicia gue brola de la fe. Santander, 1982, pp. 63-127. Todo el articulo es una excelente respuesta a aquelia objeción.

40. I. Ellacuria, op, cil., pp. 153-178. Se analiza aqui a los pobres como lugar tcológico de la manirestación de Dios, de la vivencia de la le y de la renexión teológica. 
41. W. Kasper op. cit., p. I I, litulo de la primera parte del libro que llega hasta la p. I 5R, y dounde no se cita más que los autores consagrados de la filosoria y cologia clásica y ell li detualidad, práclicamente sólo a pensadores alemanes.

42. Ibid., p. $17 \mathrm{~s}$.

43. Ibid., p. 78.

44. J. L. Sicre Los dioses olvidados. Poder y riqueza enl los profelas preexilicos. Madrid, 1979. En los estudios exegéticos "la idolatria parece haberse convertido ell una piesa de musto, sin interés vital ni actualidad para gran parte de los escrituristas," p. 16.

45. Ibid.

46. "Los profetas sacaron de este (el primer) mandanienıo una conclusión complèamenle nueva cuando lo aplicaron a la divinización de los instrumentos terrenos de poder." Teologia del Antiguo Tesiamento l, Salamanca, p. 269.

47. Misión Abierla, p. 7.

48. lbid., p. 9.

49. J.L. Sicre, op. cil., p. 155.

50. Podría preguntarse si existe una jerarquización de los idolos en la Escritura. Idolo es lo qui tiene poder para aniquilar, para generar victimas y, según eso, varias cosas pucden serlo. Mt. 6,24 menciona la conocida sentencia de Jesús: "Nn se puede servir a Dios y al dinero." Quc el dios Mammón sea elegido conscienteraente por Jesús para jerarquizar la idolatría no es claro exegéticamente; pucde liungir como ejemplo, según algunos, de la cxclusividad dtا servicio a Dios.Pero Sicre comenta: "El hecho de que Jesús, al querer concretar un posible rival de Dios, haga referencia a Mammón, demuesira que este tema era capital para él y que consideraba la riqueza como el peligro más grande a la hora de servir a Dios," op. cit. p. 164.

51. CFR. H. Wolf, Dodekapropheron I, p. 304, citado en P. Miranda, Marx y la Biblia. Salamanca, 1972, p. 74.

52. Cfr. J.L. Sicre, Con los pobres de la tierra, Madrid, 1985, p. 448.

53. Ibid., p. 126.

54. G. Gutièrre?., El Dios de la vida, p. 30.

55. C. Tr. J. Jeremias, Teologia del Nuevo Tesıamemo I, Salamanca, 1974, p. 122.

56. P. Miranda, op. cil., p. 140.

57. Un campesino de Brasil decia: "La Biblia es un libro de los pobres, es un libro para los pobres, y se ha escrito para que no haya pobres."

58. Esto es muy claro en la Iglesia de los pobres y en la teologia que se hace desde y para ella; cfr. J. Sobrino, "El Valicano Il y la Iglesia en Amèrica Latina," en C. Florisıán y J.J. Tamayo, El Valicano II, veinte ahos después, Madrid, 1985, pp. 105-134.

59. C「r. op. cil., pp. 59.67.

60. lbid., p. $62 \mathrm{~s}$.

61. Ibid., p. 63.

62. O Michel, Der Brief an die Romer, Göltingen, 1966, p. 66, cilado en op. cil., p. 63.

63. E. Käsemann, La llamada a la liberiad. Salamanca, p. 35.

64. Esta es una intuición que aparece en los teólogos - veáse las obras ciradas de G. Gutièrres, las de L. Boff, etc.—y también en algunos obispos - véase la identificación que hizo Mons. Romero enire el siervo y el pucblo salvadoreño. I. Ellacuria la ha elaborado en profundidad en "El pueblo crucificado," en op. cil., pp. 25-63.

65. I. Ellacuria. "Los pobres, "lugar Ieológico" en América Latina," en op. cil., pp. 153-178.

66. Hablar de Dios desde el sufrimiento inocente, p. 19.

67. "Los indios "crucificados." Un caso anónimo de martirio colectivo," Concilimm 1983, 183, p. 387.

68. Cfr. W. Kasper, op. cil., pp. 187ss.

69. G. Gutiértez, op. cir., p. $21 \mathrm{s.}$

70. No hay que olvidar que Medellin enunció entre los signos de los tiempos el anhelo de liberación de todas las esclavitudes como lruto del Espiritu.

71. "Camino que uno es," en Cantares de la entera hibertad, Managua, 1984, p. 47.

72. Ibid., p. 48 .

73. El Dios de la vida, p. 6s.

74. Frase de los campesinos de Aguilares, repetidas en la novedad que quierc expresar de diversas formas por muchos otros campesinos. Esa novedad suya propia la relacionaron con la nove- 
dad que les venia de fuera a traves de Mons. Romero y tantos otros profetas, evangelizadores y mártires.

75. Cfr. J. Sobrino, La Resurreccion de la verdadera Iglesia, pp. $101 \mathrm{s.}$

76. G. Gulierrez, Beber de su propio pozo, Lima, 1983, p. 144.

77. La experiencia del ser perdonado gratuitamente por el pueblo pobre como mediación del ser perdonados por Dios la hemos analizado en "América Latina: lugar de pecado, lugar de perdón," Concilium, 1986, 204, pp. 228-233.

78. G. Gutiérrez, Hablar de Dios..., p. 213.

79. G. Guliérrez, Beber de su propio pozo, p. 143.

80. Esta fenomenologia la hemos elaborado más en detalle en "Lo divino de luchar por los derechos humanos," Liberacion con espiritu. Santander, 1985, pp. 127-140.

81. En este trabajo sólo hemos considerado los problemas planteados para la teologia desde el ateismo y la idolatria, desde el primer y el tercer mundo latinoamericano. Pero la problemática es más amplia. Desde Asia, sobre todo, se escuchan críticas a planteamientos que no toman en cuenta las grandes religiones orientales, que no abordan a fondo el ecumenismo religioso, etc. Véase. como ejemplo, Raimundo Panikkar, "Dios en las religiones," Misión Abierta, pp. B5-102.

82. "Qué significa creer en Dios hoy," Misión Abierta, p. 161. J.L. Segundo, aceptando y radicalizando planteamientos semejantes muestra, sin embargo, su esperanza de que occidente esté recuperando a Dios desde la superación de la idolatria: "El hecho de que aparezca en el horizonte la posibilidad de una nueva organización de convivencia que supere la dialéctica dominante-dominado, constituye como el alborear de una nueva imagen más auléntica y más profunda de Dios, de tal manera que podemos decir, por otro lado, que nunca tampoco en occidente hemos estado tan próximos del descubrimiento del verdadero rostro de Dios," op cit., p. SOs. 